\title{
On Kentrodoris and Jorunna (Gastropoda Opisthobranchia)
}

\author{
Eveline d. B.-R. Marcus \\ Departamento de Zoologia, Universidade de São Paulo \\ Caixa Postal 6994, 01000 São Paulo, Brasil
}

\section{A B S T R A C T}

The 15 species previously ascribed to Kentrodoris and Jorunna are revised. The result is that 6 species are valid, 3 had already been assigned to other genera, 1 is a junior synonym, and 5 cannot with certainty be allotted to the present group. On the other hand, from older detailed descriptions 3 were found to differ from the species they had been ascribed to and are to be separated as new species: alisonae, malcolmi, and zania. Two new species are described, luisae and lemchei. Awuka spazzola was found to belong to Jorunna.

The distinction between Kentrodoris and Jorunna is still in Grassé's Treatise (Odhner, 1968: 871) based upon Bergh's diagnoses of 1876. Bergh had confounded the vestibular stylet and unarmed penial papilla of his species with a penial stylet and unarmed vestibular gland, and separated Kentrodoris with penial stylet and unarmed vestibular gland from Doris Johnstoni (= tomentosa), in which Alder \& Hancock (1845) had recognized the vestibular stylet and unarmed penial papilla. For the latter species Bergh created the genus Jorunna. The present examination of 9 species and detailed descriptions of 2 others revealed that all the 10 sufficiently described species have their stylet in the duct of the vestibular gland and an unarmed penis. The only with a cuticularized male duct is Kentrodoris rubescens, the type species of Kentrodoris. All the others belong to Jorunna.

\section{R E S U M O}

As 15 espécies anteriormente descritas como Kentrodoris ou Jorunna são revistas. O resultado é que 6 espécies são válidas, 3 já tinham sido removidas para outros gêneros, uma é sinônimo, e 5 não podem com certeza ser colocadas no presente grupo. Por outro lado, descrições pormenorizadas de 3 materiais, identificados com outras espécies, revelam tratar-se de 3 espécies novas, Jorunna alisonae, J. malcolmi e J. zania. Além disso, 2 espécies novas são descritas, J. luisae e J. lemchei. Awuka spazzola revelou-se como Jorunna.

A distinção entre Kentrodoris e Jorunna no Tratado de Grassé (Odhner, 1968: 871) baseia-se ainda nas diagnoses de Bergh (1876). Bergh tinha, nas suas 
espécies, confundido a papila penial inerme e o estilete da glândula vestibular, e descrito o gênero Kentrodoris com estilete penial e glândula vestibular inerme. Em Doris johnstoni (= tomentosa) Alder \& Hancock (1845) haviam acertadamente reconhecido a papila penial inerme e o estilete da glândula vestibular. Para esta espécie Bergh criou o gênero Jorunna (1876). O meu estudo de 9 espécies, como também boas descrições de 2 espécies ulteriores, mostram que todas as 10 espécies suficientemente conhecidas têm estilete na glândula vestibular e a papila penial inerme. A única espécie com duto masculino cuticularizado é Kendrodoris rubescens. Todas as outras espécies pertencem a Jorunna.

\section{Z U S AM M E N F A S S N G}

Die 15 Arten, die als Kentrodoris oder Jorunna benannt worden waren, werden revidiert. Das Ergebnis ist, dass 6 Arten gültig sind, 3 waren schon früher anderen Gattungen zugeschrieben worden, eine ist ein Synonym, und 5 können nicht mit Sicherheit zu den behandelten Gattungen gestellt werden. Andererseits ergab sich aus den genauen Beschreibungen von Material, das mit älteren Arten identifiziert worden war, dassen es sich um 3 neue Arten handelt, Jorunna alisonae, J. malcolmi und J. zania. Ferner werden 2 neue Arten beschrieben, J. luisae und J. lemchei. Awuka spazzola wurde als zu Jorunna gehörig erkannt.

Die Unterscheidung von Kentrodoris und Jorunna in Grassé's Handbuch (Odhner, 1968: 871) benutzt noch Bergh's Diagnosen von 1876. Bergh hatte bei seinen Arten die unbewaffnete Penispapille und das Stilett an der Vestibulardrüse verwechselt, und die Gattung Kentrodoris mit Penisstilett und unbewaffneter Vestibulardrüse beschrieben. Für Doris johnstoni (= tomentosa) hatten Alder \& Hancock (1845) richtig den unbewaffneten Penis und den Stachel an der Vestibulardrüse erkannt. Auf diese Art gründete Bergh (1876) die Gattung Jorunna. Meine Untersuchung von 9 Arten sowie gute Beschreibungen von weiteren 2 Arten ergeben, dass alle 10 genügend bekannten Arten ihr Stilett an der Vestibulardrüse und einen unbewaffneten Penis haben. Die einzige Art mit kutikularisiertem männlichem Dukt ist Kentrodoris rubescens, die Typus-Spezies von Kentrodoris. Alle anderen Arten gehören zu Jorunna.

\section{N T R O U C T I O N}

The classification of a dorid from Brasil made it desirable to revise the Kentrodorididae. Odhner (1926a: 53; 1934: 232;1968: 871) found the definition of the families or subfamilies of the Eudoridacea often unsatisfactory. The genera may have affinities with several different groups of dorids, and are allotted to different families or subfamilies by different authors. Hence Edmunds' attitude not to attempt to classify his species into subfamilies $(1971: 340,361,392)$ is understandable. Edmunds' discussion (1971: 359, 361) of Halgerda minor (Eliot, 1903) and Asteronotus cespitosus (van Hasselt, 1824) points to our insufficient information about many of the species, resembling one another in some features and differing in others. It is easy to place Kentrodoris in the Kentrodoridinae (Bergh, 1892: 135), but in this way we would get a subfamily for every genus. Only with further detailed analyses of the less well-known species can the family systematics be improved. 


\section{A C K N O W L E D G M E N T S}

To the Director of the Research Base of the Oceanographic Institute, University of São Paulo, at Cananéia, Dr. Victor Sadowsky, I am grateful for his hospitality, and to Mr. Julio Cardoso, Cananéia, for help with collecting at the Ilha do Cardoso. To Dr. Luise Schmekel and Prof. Pio Fioroni I owe a very pleasant sojourn at Münster, and the opportunity to study Dr. Schmekel's rich material of Mediterranean Jorunna. Dr. Annetrudi Kress-Basel sent me specimens and gave me live ones at Plymouth. Dr. Henning Lemche gave me some specimens from the North Sea and Ireland, as well as nomenclatorial advice. Prof. E. Alison Kay - Honolulu sent me three of her specimens which allowed for a comparative study of J. alisonae, spec. nov. Dr. Thomas E. Thompson - Bristol gave me one of his specimens of $J$. pantherina Angas, 1864, to complete his description and his figures (in press). Dr. Malcolm Edmunds - Preston gave me drawings and specimens of his African materials, and supported my opinions by letters and personally at Plymouth. He also revised my manuscript at an early stage. Dr. Joseph Rosewater sent me Xerox copies and a specimen of Kentrodoris funebris from the Smithsonian Institution and allowed me to dissect it. Dr. Ian R. Ball took colour photographs of my Brasilian animal alive and helped me linguistically. Dr. Thomas Gascoigne xeroxed a paper for me. Dr. Gordon Robilliard kindly reported his observations on albinistic specimens. Dr. Thomas E. Thompson furnished sections of the British tomentosa before I had the occasion to see them alive. From Dr. Roger N. Hughes I received a specimen of Kentrodoris rubescens collected at Aldabra, and from Dr. John Taylor a second one from the British Museum with permission to dissect it. Dr. William B. Rudman and Mr. Robert Burn gave me information by letters. Dr. Wulf Greve was very helpful at Helgoland and photographed the gills of living animals for me. I enjoyed a week at the Biologische Anstalt, Helgoland, where $\mathrm{Mr}$. Holtmann provided 12 big living specimens which spawned in his aquarium.

For some days I had the pleasure to visit the Plymouth Laboratory of the Biological Association, U. K., and to meet Dr. Malcolm Edmunds and Dr. Annetrudi Kress. The Deutsche Akademische Austauschdienst granted me a contribution towards my trip. I wish to express my sincere gratitude to all the above mentioned.

\section{List of the species of Kentrodoris and Jorunna}

(The species seen are marked + , those whose allotment is doubtful, ?) non Doris maculosa Cuvier, 1804; Pruvot-Fol (1934b: 221) = Discodoris $m$.

+1 Kentrodoris rubescens Bergh, 1876; Indopacific. Type species of Kentrodoris

+ 2. Jorunna tomentosa (Cuvier, 1804); Europe. Syn. Doris johnstoni Alder \& Hancock, 1845. Type species of Jorunna

+ 3. Jorunna funebris (Kelaart, 1859). Indopacific. Syn. Kentrodoris annuligera Bergh, 1876 
+ 4. Doris pantherina Angas, 1864; Australia

5. Jorunna gigas (Bergh, 1876); Indopacific

non Doris inframaculata Abraham, 1877; Bergh (1888a: 58) and Farran (1905: 336) = Platydoris $i$.

? Doris infranaevata Abraham, 1877; Mediterranean

Jorunna ? atypha Bergh, 1881: Mediterranean

6. Kentrodoris (?) labialis Eliot, 1906; Indopacific

? Kentrodoris nigra Risbec, 1928; Pacific

? Kentrodoris pseudofusca Risbec, 1928; Pacific

+7 Jorunna spazzola (Marcus, 1955); Atlantic

? Jorunna marchadi Risbec, 1956; Pacific

non Jorunna hartleyi (Burn, 1958; 1969: 82) = Rostanga h.; Australia

+ 8. Jorunna alisonae, spec. nov., pro Jorunna tomentosa Kay \& Young, 1969; Pacific

+ 9. Jorunna malcolmi, spec. nov., pro Jorunna tomentosa Edmunds, 1971; Atlantic and Indian Ocean

10. Jorunna zania, spec. nov., pro Kentrodoris funebris Edmunds, 1971; Indian Ocean

+11 Jorunna luisae, spec. nov.; Mediterranean

+12 . Jorunna lemchei, spec. nov.; West Ireland

Key to the sufficiently described species

1 With dark stripes on notum; radular teeth blunt

- No dark stripes; teeth pointed

rubescens

2 With dark rings and spots on light notum 2

- No dark rings

3 Tips of tentacles black; penial papilla bulbiform

- Tips of tentacles light; penial papilla minute

4 With broad, flat tentacles (Fig. 22)

- With pointed tentacles

5 With labial rodlets ..

- Without labial rodlets

6 With 6 tripinnate gills

- With 8-15 bi- to tripinnate gills

7 Penial bulb unarmed, muscular

- Penial bulb with several cuticular spines

8 Male duct ending without papilla

- Male duct ending with papilla

9 Female gland mass of normal size (Fig. 27, m); penial papilla small

tomentosa

lemchei

malcolmi

- Female gland mass very small (Fig. 39, m); penial papilla large, $0,8 \mathrm{~mm}$

10 Male atrium not much longer than penial papilla

- Male atrium considerably longer than penial papilla

11 Penial papilla minute, 0,06 $\mathrm{mm}$

- Penial papilla small, 0,2 mm 
This key is artificial and may serve as long as there are no more numerous specimens to show the variability. The number of slender marginal teeth and their denticles has already proved to be highly variable, as well as the shape of the labial areae of rodlets. As the four last species of the key occur far apart, I prefer not to lump them but to maintain them distinct.

The known characters of labialis are not sufficient to distinguish it in this key.

Diagnosis of the genus Kentrodoris Bergh, 1876.

Doridids with stiffened notal tubercles. Lips unarmed. Radula without rhachidian tooth. The laterals are simple, blunt hooks. Prostatic gland acinous. Male duct sheathed, ending without stylet. Vagina going inward from the common atrium, spermatheca and the loculated spermatocyst in serial order. Vestibular gland with a stylet located at the inner end of the vestibule which opens near the male atrium.

Type species: Kentrodoris rubescens Bergh, 1876: 413.

As Edmunds (letters of 27.II. and 19.XI.1974), who had seen live animals, supposed from its very different aspect, rubescens must be separated generically from the rest of the species. The soft notum, the high gills, the acinous prostate, the loculated spermatocyst, and the sheathed male organ distinguish rubescens from the rather uniform species of Jorunna.

\section{Kentrodoris rubescens Bergh, 1876 Figures 1-8}

Kentrodoris rubescens Bergh, 1876: 413, pl. 49, figs. 14-19, pl. 50 , figs. $1-8 ; 1874$, pl. 33 , fig. 8

Kentrodoris rubescens Eliot, 1903: 374, pl. 34, fig. 7; 1910b: 424

Kentrodoris rubescens, var. Bergh, 1905: 62, pl. 5, figs. 1-11

Kentrodoris rubescens Dawydoff, 1952: 110

Distribution. - East Africa; Indian Ocean; Philippines; Annam; Siam; China Sea; New Britain, Ralum.

Material. - Indian Ocean, Aldabra Island, $9^{\circ} \mathrm{S}, 45^{\circ} \mathrm{E}$, one dry specimen, Roger N. Hughes leg., June 1968; Aldabra Island, one wet specimen, John D. Taylor leg., 1969 (Brit. Mus. acc. n. ${ }^{\circ} 2222$ ).

Description. - Due to the fact that there are some slight differences between the two studied specimens, I give their descriptions separately. The dry animal is $15 \mathrm{~mm}$ long and $5.5 \mathrm{~mm}$ hight. Bergh's original specimens were $11 \mathrm{~cm}$ long, alive, Eliot's (1903), even $17 \mathrm{~cm}$; later finds were $67 \mathrm{~mm}$ (Eliot, 1910b) and $45 \mathrm{~mm}$ (Bergh, 1905). The colours are described as dull pinkish, reddish or greyish, with irregular longitudinal darker, anastomosing lines, bluish black or chocolate, especially on the gills, but also on the upper lip and on the genital papilla, and on the upper and under sides of the foot. The notal tubercles were described as conical, 


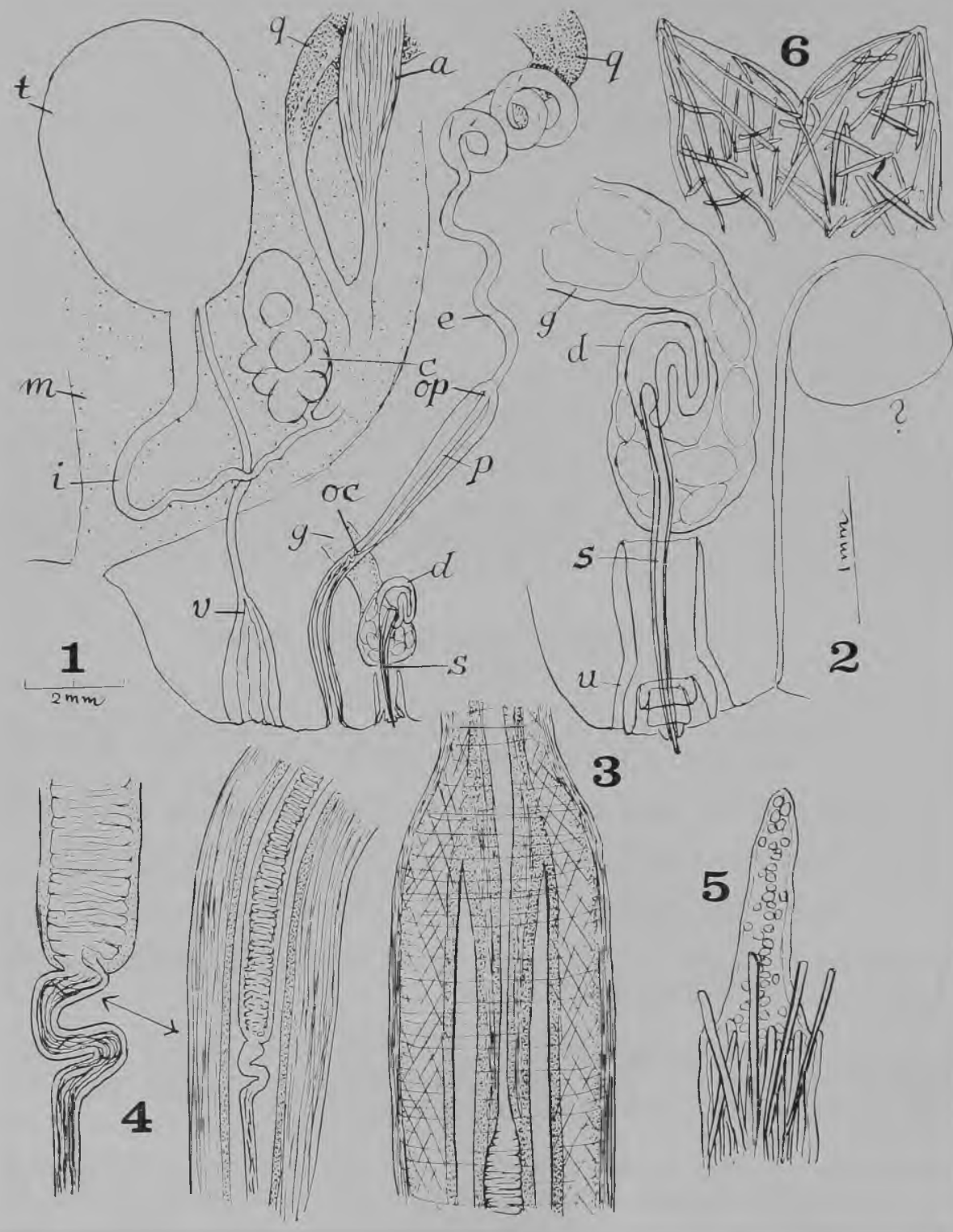

Figures 1-6 - Kentrodoris rubescens from Aldabra

1 - Diagram of reproductive organs of dry specimen softened. 2 - Vestibular stylet of same with higher power. 3 - Root of penis (op) with higher power. 4 - Cuticularized male duct (oc) with higher power. 5 - Caryophyllidium of wet specimen. 6 - Notal tubercles, copied from Bergh (1876, pl. 49, fig. 15). 
stiffened by irregular spicules not projecting over the tip (Bergh, 1876: 415 , pl. 49, fig. 15; Fig. 6). In my softened specimen they are caryophyllidia. On the black stripes they have a belt of pigment and a light tip. In several places the notal papillae are in regeneration, evidently due to injury. The spicules are broken. The spotted rhinophores of the present animal have 20 foliations. Bergh indicated 30 in 1876, 50 in 1905. The finger-shaped tentacles are slightly flattened (Bergh, 1876: 414). The notched upper lip of the bilabiate anterior border of the foot is streaked with black. There are seven quadripinnate gills, described by Eliot (1910) as "rising out of their cup like a sleeve"

The labial cuticle is smooth, without rodlets. The radular formula

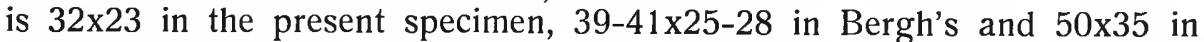
Eliot's larger animals. The first lateral is hardly different from the rest (Fig. 7), but provided with a denticle or projection on its base in Eliot's description (1910b). The laterals are blunt (Bergh, 1876, pl. 49, fig. 19); only the two outermost, the marginal teeth, are pointed (Fig. 7). The stomach is free, not covered by the digestive gland.

The reproductive organs (Figs. 1-4) could not be analyzed completly in the softened specimen. I could identify the parts with Bergh's figures $(1876 ; 1897)$ and could confirm the supposition that Bergh had confounded the vestibular stylet and the unarmed male papilla. The present animal is smaller than those studied by Bergh, hence the measurements of the reproductive organs are smaller than his.

The everted genital papilla projects from the hyponotum. It bears black pigment stripes as figured by Bergh (1905: 65, pl. 5, fig. 8). The genital ducts open separately on its tip. The spermoviduct leaves the wide ampulla (a) and divides into sperm duct and inner oviduct; the latter enters the female gland mass $(\mathrm{m})$. The former widens and becomes prostatic (q), its epithelium forming glandular acini. This part is curled upon itself. The following winding one is narrow and muscular. It widens (Figs. 1, 3), and its lumen becomes cuticularized, while an outer layer sheathes the inner tube, as, e. g., in Polycera (see Marcus, 1955: 159, fig. 200). The inner cuticle forms transverse folds in its ental, wider part (Fig. 4). In the outer, narrow part the folds are longitudinal. The outer opening of the male duct was hidden in the dense pigment of the body wall. Bergh (1905: 65) described the "duct of the vestibular gland" as ending in a small papilla grooved longitudinally. Beside the male opening the wide vagina enters (Fig. 1, v). Its epithelium is thrown into longitudinal folds. The vaginal duct narrows and opens into the big spermatheca $(t)$. The insemination duct (i) leaves the latter in serial arrangement. It begins very wide and narrows farther inward, ending in the gland mass (m), giving off a short tube to the loculate spermatocyst (c). This was also described for Bergh's variety (1905). In the present specimen the vestibule $(u)$ is in half everted state, folded around the vestibular stylet of $2.5 \mathrm{~mm}$ length (Fig. 2). A thin muscular duct forms the outlet (d) of the vestibular gland (g), of which only the ectal part containing coagulated masses of secretion was seen. It corresponds to the ectal part of the gland of Jorunna tomentosa (Fig. 48). Beside the vestibule of this specimen lies a round vesicle (Fig. 2, ?), the function of which I could not find out. 


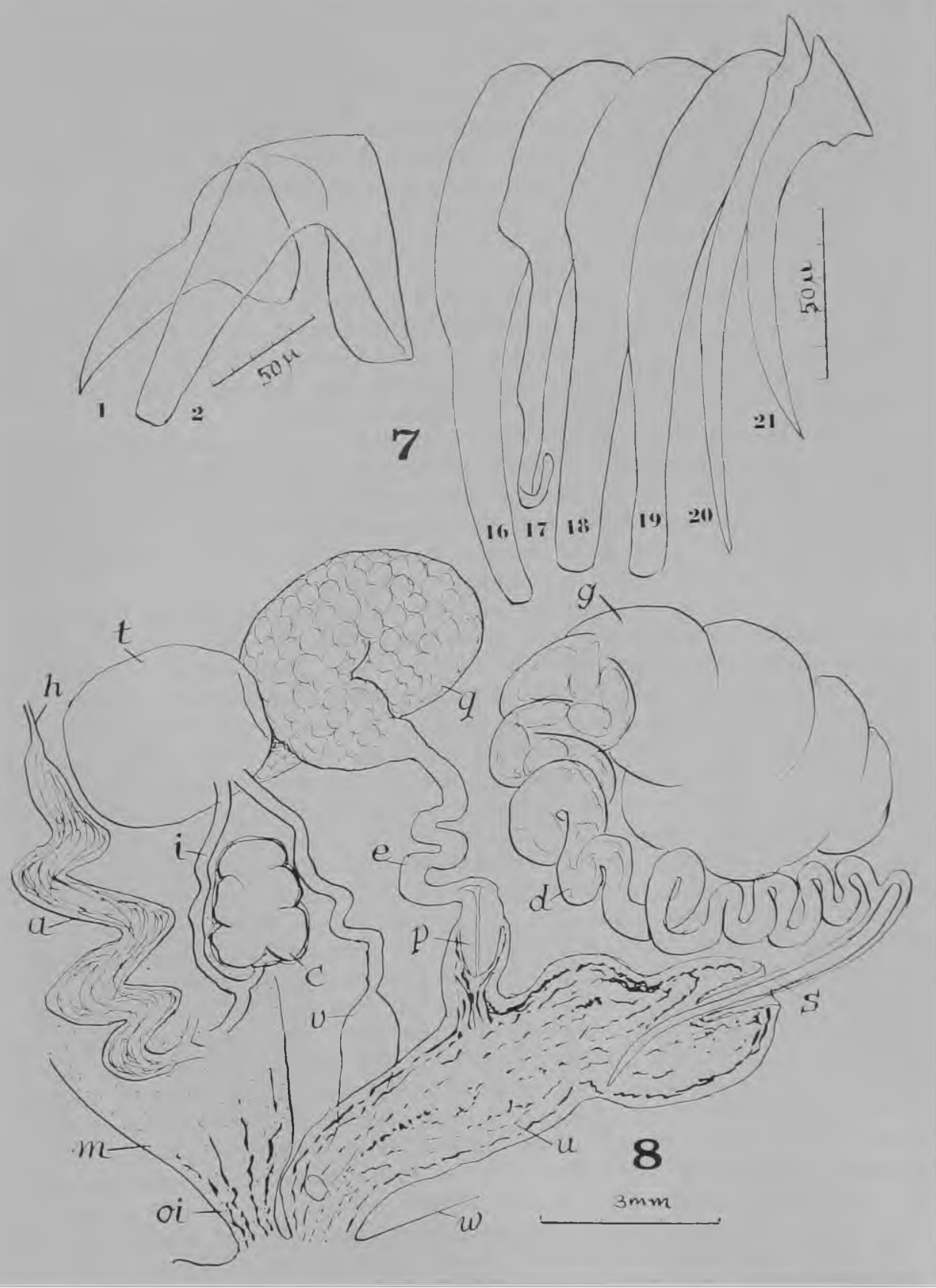

Figures 7, 8 - Kentrodoris rubescens from Aldabra 7 - Radular teeth. 8-Diagram of reproductive organs of wet specimen. 
The wet animal is $52 \mathrm{~mm}$ long, $12 \mathrm{~mm}$ high and $12 \mathrm{~mm}$ broad. Its tail is $10 \mathrm{~mm}$ long. The light brownish grey notum appears quite smooth, not wrinkled. It is covered with small, typical caryophyllidia, about $0.04 \mathrm{~mm}$ in diameter and up to $0.27 \mathrm{~mm}$ high; the spicules reach about $0.15 \mathrm{~mm}$, and the "tentacular processes" (Garstang, 1893: 50) are fully extended (Fig. 5). The notum stands out over the snout, $7 \mathrm{~mm}$ long and with a black spot. On the sides the mantle border is 3-6 mm broad, with a white under side. Its black stripes are preserved in some places. The straight borders of the rhinophore and gill pits are black. The rhinophores have about 40 leaflets. The seven quadripinnate gills project about $10 \mathrm{~mm}$. They are joined high up on their inner sides by a membrane. Their rhachis is white, that of some of the pinnules, black. The pointed tentacles are about $1.5 \mathrm{~mm}$ long. The black anterior border of the foot is bilabiate. Its upper lip with some black stripes is strongly notched, the lower lip folded. The foot is greyish yellow; its margins are wavy; on its upper side there are fine, longitudinal black streaks. The light sole has many fine, longitudinal folds.

The labial cuticle is smooth. The radular teeth, $35 \times 25.0 .25$, are blunt, equal to those of the dry specimen.

The anterior genital mass is about $12 \mathrm{~mm}$ in diameter. The winding ampulla (Fig. 8, a) enters the gland mass near the entrance of the insemination duct (i). Albumen and mucus gland measure together about $7 \times 10 \mathrm{~mm}$. The male duct goes out from the ampulla and forms a globular prostate $(\mathrm{q})$, in which the gland cells are arranged in acini. The following coiled muscular duct $(\mathrm{e})$ ends through a soft papilla with an indistinct cuticular lining ( $p$ ) in a pouch of the vestibule. It appears to be the everted phase of the retracted organ of the dry specimen. The vagina (v) is wide, its duct, narrow. It opens into the globular spermatheca ( $t$ ), from which the insemination duct leaves close beside it. Both ducts are of equal diameter. The insemination duct (i) sends a short connexion to the loculate spermatocyst (c). The vestibular gland $(\mathrm{g})$ is almost globular. I did not find any connexion with the female gland mass. Its ectal muscular part (d) is strongly coiled and contains the coagulated masses also found in the other species. The outermost, narrow part opens subterminally into the stylet pouch, from which a $6 \mathrm{~mm}$ long stylet $(\mathrm{s})$ projects into the wide, $10 \mathrm{~mm}$ long vestibule $(u)$. The inner wall of the latter shows black stripes.

Discussion. - Both animals agree with Bergh's description, aside from his confusion of the unarmed penis and the stylet of the vestibular gland. His almost acinous gland $(1876: 418)$ corresponds well to the present prostate. The small, conical papilla (1905: 65), which he considered as the outlet of the vestibular gland, is really the penial papilla. The subterminal opening of the vestibular gland duct into the sheath of the stylet in all the present examined species proves, that also Bergh's stylet (pl. 5, fig. 10) is vestibular, not penial.

The caryophyllidia of the present material (Fig. 5), contrast with the papillae of Bergh's description (1876: 415, pl. 49, fig. 15), which are carefully illustrated (copied Fig. 6). I leave these discrepancies open for future research with more ample material. 
Remarks. - Bergh distinguished the specimens from New Britain (1905) as variety of rubescens, due to a slight difference in the first lateral tooth, and the loculate spermatocyst. In the present specimens from Aldabra the first tooth is still farther different, but the spermatocyst is also loculate. As rubescens is the only Kentrodoris with longitudinal stripes, with a high tuft of gills, with blunt teeth, and with acinous prostate, and the three studied materials agree in these characters, I consider them all as rubescens.

Kentrodoris rubescens and " $K$ " gigas, both originally from the same locality, and both bigger than the other species, differ by blunt teeth in $r$., normally pointed ones in $g$., and by an enormous stylet of the vestibular gland, up to $10 \mathrm{~mm}$ long, in $r$., about $2.7 \mathrm{~mm}$ long in the $10 \mathrm{~cm}$ long $g$. Both stylets were drawn with the same magnification (1876, pl. 50, figs. 3 and 22).

Diagnosis of the genus Jorunna Bergh, 1876

Doridids with stiffened notal tubercles, generally caryophyllidia. Lips armed or unarmed. Radula without rachidian tooth. Laterals simple, pointed hooks. Marginals sometimes with irregular denticles. Prostatic epithelium smooth. Male duct ending with papilla without stylet, or even without papilla. Vagina going inward from the common atrium; spermatheca and simple spermatocyst in serial order. Vestibular gland with stylet as in Kentrodoris.

Type species: Jorunna tomentosa (Cuvier, 1804: 470)

The species of the genus are rather uniform in their reproductive organs. The two species with dark rings on the notum might be a good group. Certainly the 4 smooth-lipped species can be separated from the 4 with labial rodlets.

Awuka Marcus, 1955, is a junior synonym to Jorunna.

\section{Jorunna tomentosa (Cuvier, 1804) \\ Figures $9-19$}

Doris tomentosa Cuvier, 1804: 470

Doris obvelata Johnston, 1838 : 52 , pl. 2, figs. 4-7

non Doris obvelata Müller, Sars, 1878: 305, pl. XIII, figs. 3a-3i; = Cadlina laevis

Doris johnstoni Alder \& Hancock, 1845, fam. 1, pl. 5; 1851, fam. 1 , pl. 2 , figs. $8-10 ; 1855$, pl. 46 , fig. 4

Doris johnstoni Collingwood, 1859: 462

Jorunna johnstoni Bergh, 1876: 414; 1880: 47-52, 117, pl. 8, fig. 19 ; pl. 9, figs. $1-11 ; 1881$ : 114, pl. K, figs. 20-28; 1884: 683 , pl. 70 , figs. 21-23.

Jorunna johnstoni var. alba Bergh, 1881: 119, pl. J, figs. 17-21, pl. K, figs. $29-36 ; 1884$, pl. 70 , fig. 20 
Jorunna johnstoni Garstang, 1893: 49-52

Doris johnstoni Hecht, 1895: 546, 570, 624

non Jorunna johnstoni Vayssière, 1901: 31, pl. 3, figs. 24-27

Jorunna johnstoni Odhner, 1907: 67; 1926b: 23

Jorunna johnstoni Eliot, 1910a: 149

Jorunna johnstoni Grieg, 1913: 4

Jorunna johnstoni Brygider, 1914: 360, 395, fig. 41

Jorunna tomentosa Iredale \& O'Donoghue, 1923: 227

Jorunna johnstoni Hoffmann, 1926: 10

Jorunna tomentosa Cuénot, 1927: 268

Jorunna tomentosa Lemche, 1929: 10

Jorunna tomentosa Thiele, 1931: 436

Jorunna johnstoni Labbé, 1933: 214, figs. 2, 3

Joruna tomentosa Pruvot-Fol, 1934b: 240; ? 1951: 12; 1953:

66, pl. 3, fig. 52; 1954: 274, figs. 109, 110 (figs. 109a, b, $\mathrm{c}, \mathrm{g}$ are originals)

Jorunna tomentosa Millott, 1937: 173-217

Jorunna johnstoni Nobre, 1938: 51

Jorunna tomentosa Odhner, 1939: 35, fig. 18

Jorunna tomentosa Jaeckel, 1952: 251, 254, 257

? Jorunna tomentosa Haefelfinger, 1960: 336, 346

Jorunna tomentosa Thompson, 1960: 126; 1964: 289

Joruna tomentosa Swennen, 1961: 235

Jorunna tomentosa Wolter, 1967: 218, fig. 5

non Jorunna tomentosa Schmekel, 1968: 115, 148; = luisae

Jorunna tomentosa and J. johnstoni Odhner, 1968: 871

non Jorunna tomentosa Young, 1967: 168; Kay \& Young, 1969: 184, figs. 11,17 ; = alisonae

Jorunna tomentosa Bebbington \& Thompson, 1968: 7

Joruna tomentosa Young, 1969: 423, 427, 430

non Jorunna tomentosa Edmunds, 1971: 364, figs. 11 A-G: = malcolmi

Distribution. - From Norway, $65^{\circ} \mathrm{N}$, to the Kattegat, Öresound, Helgoland and the British, French, Portuguese and Moroccan coasts; Mediterranean: Adriatic.

Material. - From Plymouth, 3 specimens; from Helgoland, 12 specimens and spawns; from Denmark, Frederikshavns port, one specimen, $28 \times 13 \times 10$ mm, preserved, Poul L. Kramp leg., 20. July, 1948.

Description. - The present specimens measured, alive, up to $46 \times 20 \mathrm{~mm}$. Preserved, the largest was $36 \mathrm{~mm}$ long. Alder \& Hancock had some $5 \mathrm{~cm}$ long animals; Nobre's measured $80 \mathrm{~mm}$. Their height in the mid-line corresponds approximately to their breadth; the wavy notal borders are often flattened.

The colours of the living specimens vary from cream to light yellow or orange. Generally they bear two rows of irregularly distributed larger dark spots and many single melanophores (Figs. 9, 10). 


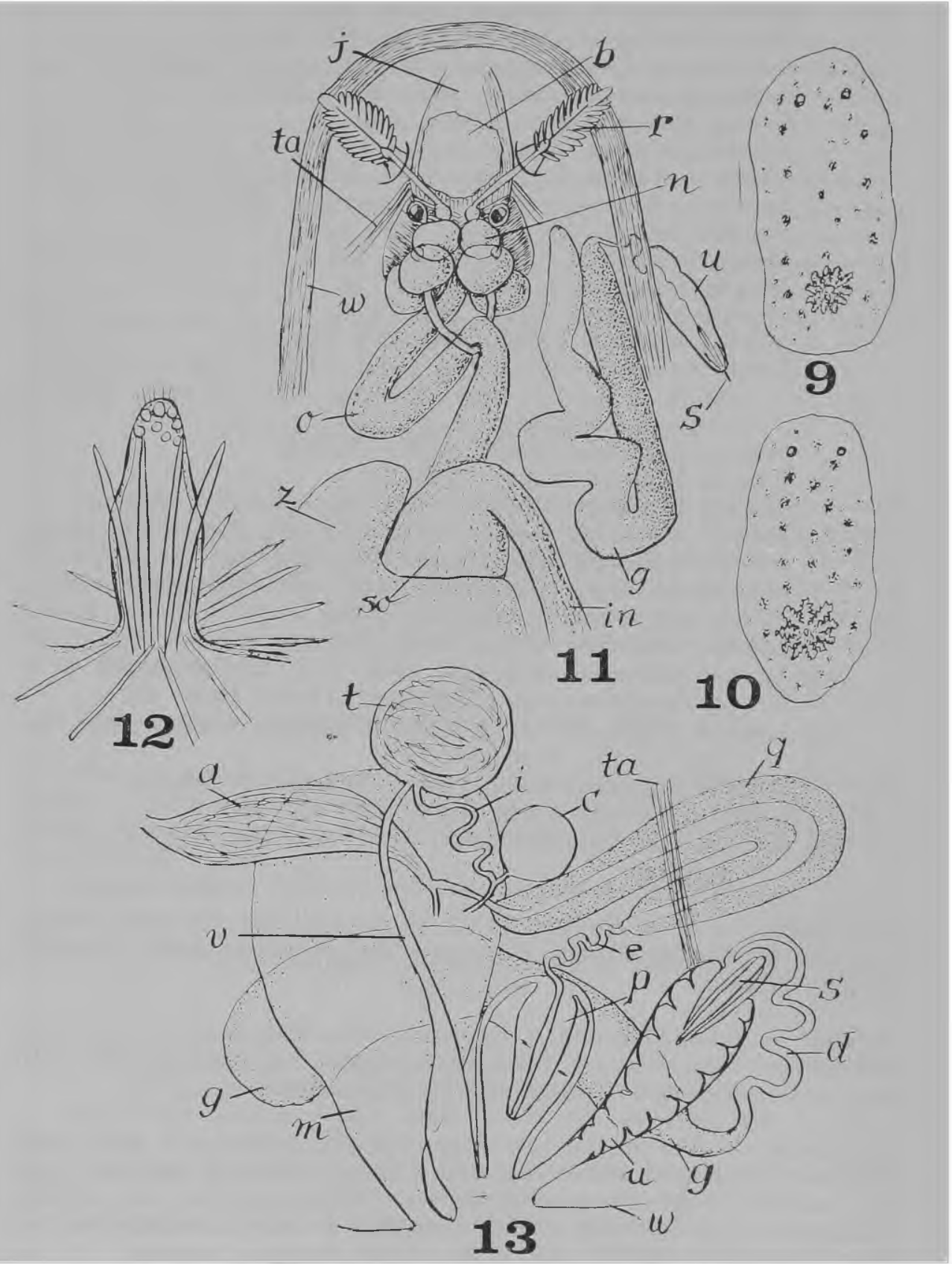

Figures 9-13 - Jorunna tomentosa

9, 10 - Sketches of living slugs from Helgoland. 11 - Anterior part of dissected specimen from Plymouth with digestive tract and vestibular gland. 12 - Caryophyllidium of living slug from Helgoland. 13 - Diagram of reproductive organs of specimen from Helgoland. 
The notal papillae are caryophyllidia with a circle of spicules projecting over the tip of the papilla (Fig. 12). In material preserved for many years most of the free parts of the spicules had been dissolved or broken. In the caryophyllidia there are refractive glands, principally in the tips.

The rhinophores have 10-20 foliations. The surface of each of these often looks as if it were split. Thus it is understandable that Bergh (1880: 48; 1881: 115, 120) indicated 25-40 foliations. The conical tentacles are pointed; they can project over the anterior border of the notum. The anterior border of the foot is bilabiate, its upper lip, deeply notched. There are 8-13, or up to 16 (Garstang, 1893: 50) bi- to tripinnate gills. Alder \& Hancock counted 15 in their largest specimens. Frequently they assume cup-shape.

The smooth labial cuticle is thickened. The radular formula is $19-24 \times 4-5.16-19 \cdot 0.16-19.4-5$. The rhachis is smooth. The innermost lateral tooth sometimes appears slightly broader than the following ones (Figs. 14, 15) and may bear a tiny denticle near the tip. The following teeth increase in height and thickness, they are hook-shaped. Their base is longer than the free cusp, e. g., base $0.22 \mathrm{~mm}$ and cusp, $0.14 \mathrm{~mm}$, in the middle of the half-row in a $32 \mathrm{~mm}$-slug. Outwards the size decreases and the base becomes shorter. The 3-6 marginals are gradually more slender. In the outermost tooth the base is only a little longer than its diameter (Fig. 14). In one specimen from Plymouth the marginals on the right side were denticulate, while those on the left side of the radula were smooth (Fig. 14).

The peritoneum is stippled with single chromatophores; also the blood glands sometimes contain such. In contracted animals the oesophagus forms a forward loop before it passes through the nerve ring (Fig. 11), as Edmunds figured it for his only specimen of Halgerda minor (Eliot, 1903) (1971, fig. $9 \mathrm{~F}$ ). The salivary glands run backward through the nerve ring and accompany the oesophagus with a slight left twist. The stomach is embedded in the digestive gland. The intestine emerges from the dorsal surface of the latter, turns to the right and runs backward to open on a ridge between the hind-most pair of gills.

The follicles of the ovotestis cover the digestive gland. The ampulla (Fig. 13,a) is distended with sperm. It gives off the male duct and enters the female gland mass $(\mathrm{m})$ almost together with the insemination duct (i). The male duct is widened by the high prostatic epithelium (q), bends back onto itself and is continued as a thin, muscular efferent duct (e), which opens through a big papilla $(p)$ into the male atrium. This unarmed muscular penial papilla is of varying aspect according to the degree of its contraction (Figs. 40, 41, 43). Relaxed it is a conical papilla, but contracted it is globular. The male atrium opens into the fundus of the common atrium. The epithelium of both penial papilla and sheath is folded longitudinally.

The female gland mass $(\mathrm{m})$ occupies the greater part of the "anterior genital mass" (Bergh). It is divided into a central hard, gelatinous yellowish albumen gland and the surrounding whitish, soft mucus gland. In contracted state the vagina (v) leaves the common atrium near its entrance. In everted state it opens on the genital papilla. The beginning 


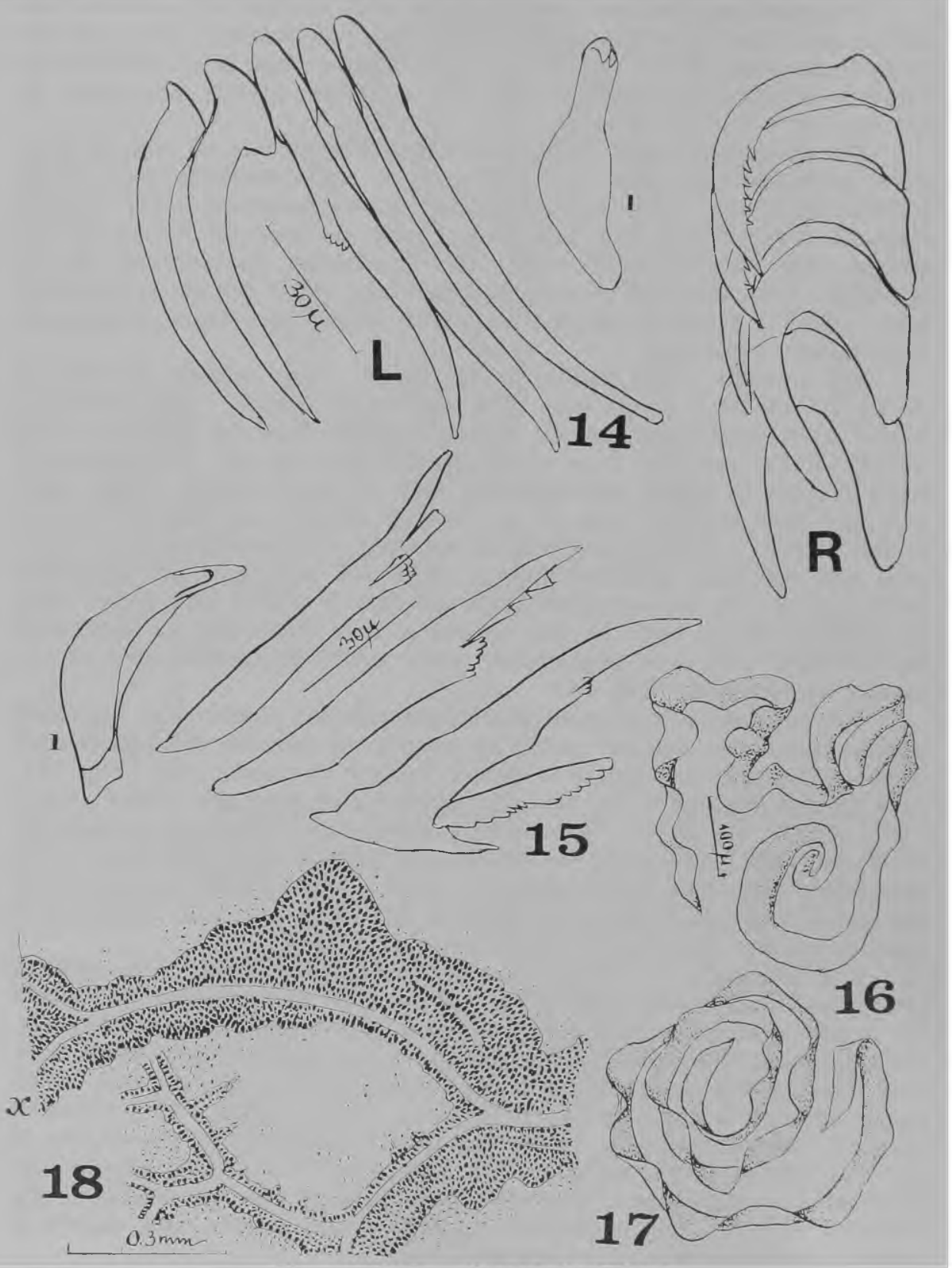

Figures 14-18 - Jorunna tomentosa

14 - Marginal teeth of right and left side of one and the same row, and innermost tooth (1), from Plymouth. 15 - Innermost tooth (1) and marginal teeth from different rows of specimen from Helgoland. 16, 17 - Spawns from Helgoland. 18 - Peritoneal epithelium with pericardial gland, total preparation, stained with carmine. 
is wide, and its epithelium is folded longitudinally. It runs straight inward to the left of the oesophagus. The insemination duct (i) leaves the spermatheca $(t)$ close to the entrance of the vagina and coils to the right, giving off a short duct to the small spermatocyst (c), and penetrates into the female gland mass near the oviduct. In one specimen there were 11 eggs in the insemination duct, and numerous ones in the spermatocyst.

The inward course of the vagina is encircled by the tubular vestibular gland $(\mathrm{g})$, from which a long, coiling duct (d) emerges and enters the muscular sheath of the vestibular stylet (s). This carrot-shaped organ surrounds the cuticular stylet and projects into the style sac, a wide diverticulum of the common atrium with circular folds of its epithelium $(u)$. The vestibular stylet is soft, so it is straight or curved, according to the state of contraction of the papilla; it may even be curved in the opposite direction to that if its papilla.

Among the specimens from Trieste Bergh found three quite white ones, preserved up to $5 \mathrm{~cm}$ long, which he described as var. alba (1881: 119125). He did not succeed in analyzing the genital organs completely. There is no description of the male duct. The length of the vestibule is not indicated, so it is not quite sure that it is a tomentosa. Possibly the white colour is due to albinism. Whitish specimens are known for Onchidoris bilamellata (Linnaeus, 1767) on the west coast of North America

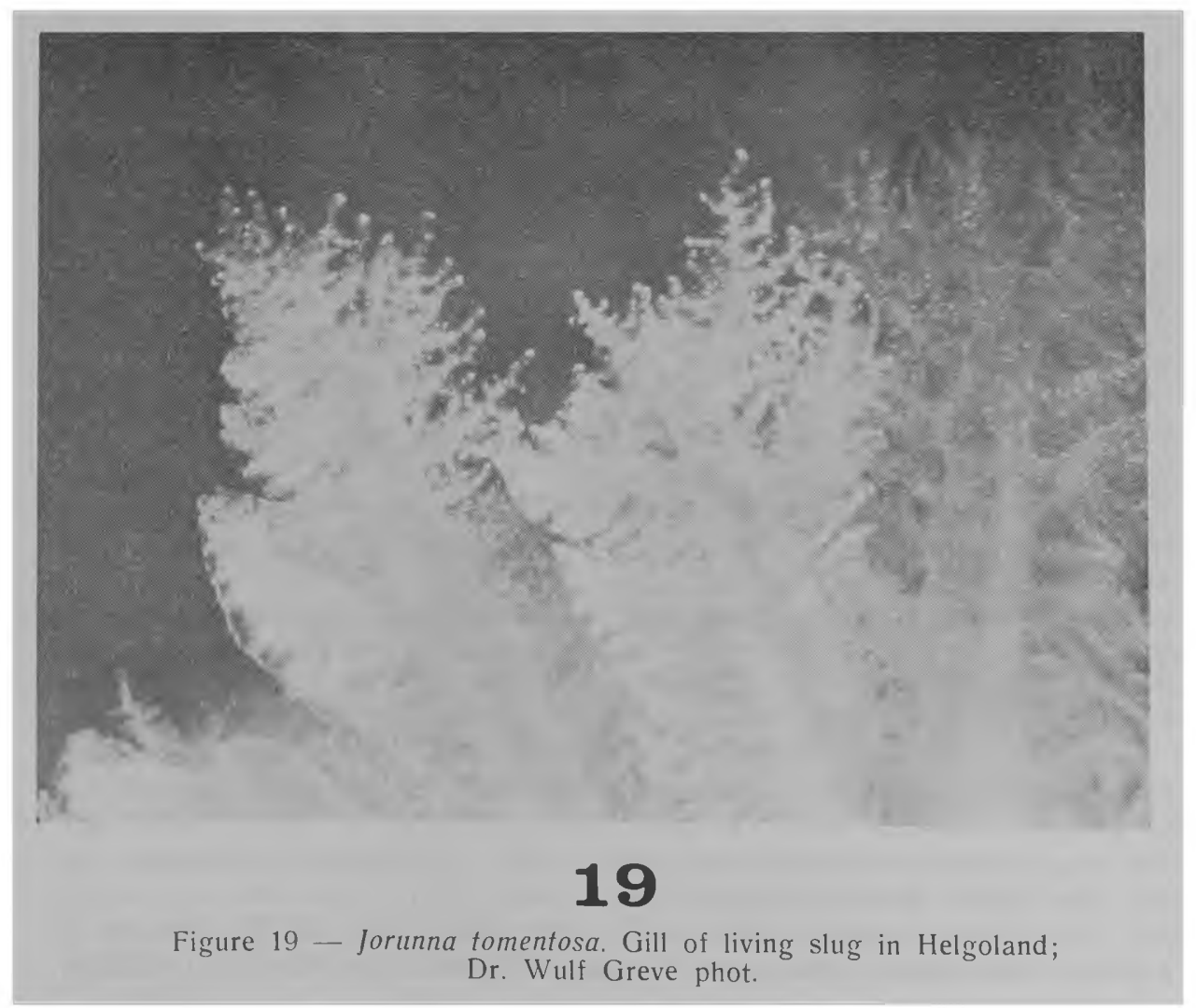


(O'Donoguhue, 1922: 126). Dr. Gordon A. Robilliard (Letter of 2.XII. 1974 ) found that as many as $2-5 \%$ of a large population were comprised of completely white individuals. I recently found a quite albinic specimen of Dendrodoris krebsii (Mörch, 1863) with red rhinophores, like an albino rabbit, among normally coloured ones (1975: 893).

Discussion. - The older descriptions of the species by Cuvier, Johnston, Alder \& Hancock, Kelaart, and others, are so short that they serve for several species. However, Alder \& Hancock gave an admirably correct figure of the reproductive organs of the British johnstoni (1851, fam. 1, pl. 2, fig. 8). Bergh (1880:48, note 3 ) criticized it, but his own figures and lettering "are not quite clear" (Odhner, 1939: 36). Bergh complained about the scarceness of material for these difficult subjects (1881: 125, note 1). Later he admitted (1884: 683) that his previous description (1880) of the reproductive organs had been incomplete. For johnstoni Bergh had indicated a penial as well as a vestibular stylet (1880: 51, pl. 9, figs. $7,10,11)$. Odhner $(1939$, fig. 18) gave a new figure of the genital organs of Norwegian tomentosa with a very short stylet to the vestibular gland and a conical unarmed penis. Edmunds' figure of his Tanzanian material (1971: 364, fig. $11 \mathrm{~F}$ ) shows a "lateral stylet which must be regarded as a penis", quite different. His species is here recognized as new, Jorunna Malcolmi.

Bergh figured the notal papillae (1880, pl. 9, fig. $2 ; 1881$, pl. K, figs. 20,21) of his Danish specimens (preserved 1870), and from Trieste (preserved 1879). He drew them as blunt pegs with the spicules not reaching the tip and not projecting at the sides. Pruvot-Fol (1954, fig. 109 ) copied Bergh's figure of 1880 . My animal from Denmark (preserved 1948) has spicules projecting from the caryophyllidia (Fig. 12).

Odhner, following Iredale \& O'Donoghue (1923) changed the name of the European species to tomentosa (1926b: 23). Later Labbé (1933) maintained johnstoni, synonymizing tomentosa, and Odhner (1968: 871) mentioned johnstoni as well as tomentosa. Vayssière (1901, fig. 24) ilustrated the caryophyllidia of his Jorunna, and in fig. 26 its labial rodlets. This character corresponds to J. luisae, spec. nov., and to Edmunds' description of the tomentosa from Tanzania, now malcolmi. Vayssière did not mention a vestibular gland nor a stylet. Pruvot-Fol's record of Jorunna tomentosa from Banyuls (1951: 12) does not indicate any characters, so its specific position cannot be judged. The same holds for Jorunna spec., Pruvot-Fol (1953: 78) from Dakar.

Some biological and anatomical data are noted in the last chapter (p. 58).

\section{Jorunna funebris (Kelaart, 1859) Figures 20A, 20B}

non Doris maculosa Cuvier, 1804: 466; = Discodoris maculosa

+ Doris funebris Kelaart, 1859: 293

? Doris funebris Alder \& Hancock, 1864: 122, pl. 30, figs. 9, 10

+ Kentrodoris annuligera Bergh, 1876: 423, pl. 41, fig. 1 (1875), 
pl. 52 , figs. $3-16 ; 1890$ : $922-924$, pl. 85 , fig. 8 , pl. 89 , fig. 12 ; 1897 : 98 , pl. 12 , figs. 1-6

+ Kentrodoris maculosa Eliot, 1906: 649, 1001; 1907: 85

+ Doris funebris Kelaart, O'Donoghue, 1933: 222, pl. 19

non Doris maculosa Cuvier, Pruvot-Fol, 1934a: 84; 1934b: 220223; = Discodoris maculosa

? Kentrodoris funebris Allan, 1947: 454, pl. 43, figs. 10-12 non Kentrodoris funebris Risbec, 1956: 17, figs. 18-22; = ? Peltodoris

? Kentodoris (err. pro Kentrodoris) funebris Kenny, 1960:226; 1970: 88

? Kentrodoris annuligera Engel \& van Eeken, 1962: 25, figs. 2, 3

+ Kentrodoris funebris Marcus, 1965: 276

? Kentrodoris maculosa Guang $\mathrm{Yu} \& \mathrm{Si}, 1965: 11$, pl. 3, fig. 6 non Discodoris sp. Lim \& Chou, 1970: 99, figs. 1 F, 3 L, 7 A, 7 B, $104 ;=$ Discodoris annuligera Bergh. This is a Discodoris by the shape of its jaw plates (fig. $1 \mathrm{~F}$ ), possibly maculosa non Kentrodoris funebris Edmunds, 1971: 366, figs. 12, 13; = zania, spec. nov.

Distribution. - The only certain localities are the Red Sea, Ceylon, the Philippines, and the Palau Islands. All the other previous indications are not specific.

Material. - Palau Islands, Uwayama Bay, Reef at South end of Gua-Zima (Island XV), St. 92/10t 1110, 14.VIII.1955, Frederick M. Bayer leg., one specimen; U. S. Nat. Mus. n. ${ }^{\circ} 57665$.

Description of the present material. - Length $23.5 \mathrm{~mm}$, contracted; breadth $11 \mathrm{~mm}$, notal borders folded in; height $9 \mathrm{~mm}$. With spread notal borders the breadth is $13 \mathrm{~mm}$. The animal is whitish with few black rings in the middle of the notum and a series of black spots around the margin and on the upper side of the foot. The rhinophoral leaflets are black, the rhachis and the stalk as well as the tip are white. The gills are white except for a stripe of black pigment accompanying the afferent vessels. The conical, pointed tentacles have black tips. The notal papillae are stiffened by spicules, probably true caryophyllidia, but after 19 years in the preserving liquid the free tips of the spicules have dissolved.

The big rhinophores have about 12 leaflets. The bilabiate anterior border of the foot has a deeply notched upper lip with some black spots on it. There are six at least tripinnate gills, far extruded, very similar to Kelaart's drawing of the living animal (O'Donoghue, 1933) and Semper's painting (Bergh, 1875, pl. 41, fig. 1).

In the wall of the buccal cavity there are some melanophores. The labial cuticle is smooth without rodlets. The radular formula is $28 \times 1-3.25-28 \cdot 0.25-28.1-3$. The innermost tooth, $0.11 \mathrm{~mm}$ high, is different from the others (Fig. 20A). It looks as if is was malformed, but it is equal on both sides in all rows. The following laterals are higher and typically hook-shaped, though a little broader than in the other species. 


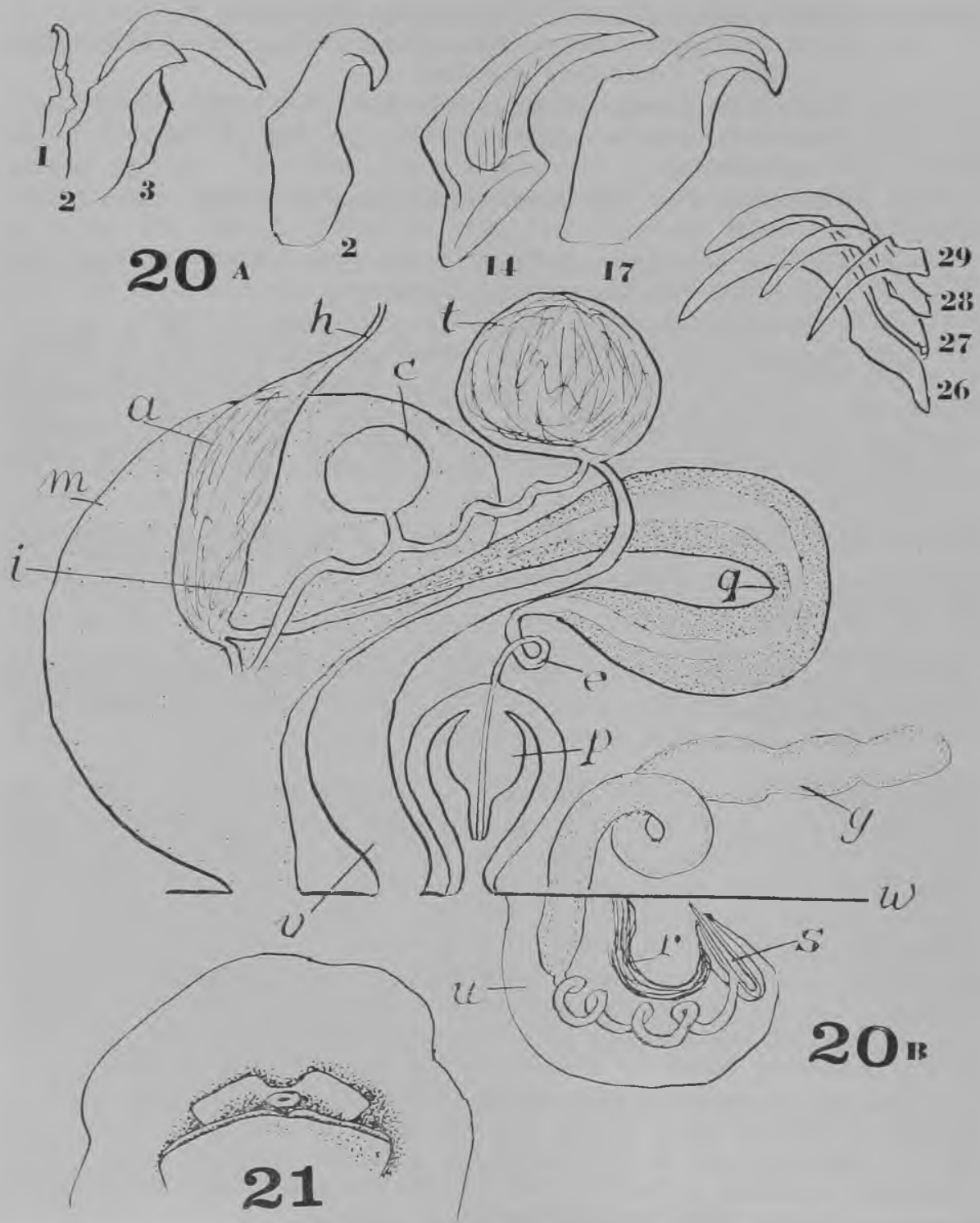

Figure 20 - Jorunna funebris from Palau

$20 \mathrm{~A}$ - Teeth. $20 \mathrm{~B}$ - Diagram of reproductive organs.

Figure 21 - Jorunna (?) atypha, Head in ventral view, copied from Bergh (1881, pl. J, fig. 22). 
They increase to $0.35 \mathrm{~mm}$ in height. The outer teeth diminish in size, mainly by reduction of the base, which is quite short in the outermost one. The oesophagus loops before it passes through the nerve ring, probably due to contraction. The salivary glands are ribbon shaped and course asymmetrically; the left, behind the nerve ring, runs dorsally to the right and then it curves left and is fixed to the digestive gland on the left side. The stomach is covered by the latter.

The outer reproductive organs are everted (Fig. 20B). The ovotestis forms a thin layer over the digestive gland. The tubular ampulla (a) courses to the right; the spermoviduct gives off the male duct and enters the large female gland mass. The male duct widens and becomes glandular (q), folds onto itself and ends with a thin, muscular part (e) in a bulbar papilla ( $p)$, which Bergh (1890: 924) described as radially furrowed. The latter projects into the strongly muscular male atrium.

The vagina $(v)$ opens beside the male aperture with a wide beginning and narrows towards the globular spermatheca $(t)$. This is situated to the left of the oesophagus, in front of the digestive gland. Beside the entrance of the vagina the insemination duct (i) goes out, winds, and receives a short duct from the small spermatocyst (c), and opens into the female gland mass $(\mathrm{m})$ near the inlet of the oviduct. In front of the male aperture the everted vestibule $(u)$ forms a large papilla, near the inner end of which the duct from the vestibular gland $(g)$ enters the muscular sac lodging the $0.8 \mathrm{~mm}$ long cuticular stylet (s).

The first specimen Bergh described was preserved $5.5 \mathrm{~cm}$ long. Its vestibule, called "Penissack" by Bergh, measured $8 \mathrm{~mm}$ in length, and the stylet, $2.2 \mathrm{~mm}$. His figure $(1876$, pl. 52, fig. 14, h) of the bulbiform papilla of the vestibular gland conforms well to the present specimen. Eliot's material (1906) showed the black tips of the tentacles.

Discussion. - The specimen I received from the Smithsonian Institution had been labeled Kentrodoris funebris by Marcus (1965: 276). At that time we had classified a collection of 130 opisthobranchs belonging to 53 species, and had not described the known species. Now while reviewing the genus, I made a comparative study, and am glad I came to the same result as ten years ago. The dissection showed that the reproductive organs differed distinctly from the species Edmunds has called funebris, while they were identical with the figures of Bergh's annuligera, though Bergh was rather vague in the description of the genital organs. Bergh synonymized these species in 1897 Eliot (1906: 650) examined a specimen sent to the Hancock Museum by Kelaart himself from Ceylon, and found the innermost radular tooth similar to that of Bergh's annuligera, so he accepted the synonymy, and I follow them. Edmunds' animal is not conspecific with funebris and receives the name Jorunna zania, spec. nov.

Bergh had noted the ribbon-shaped salivary glands in his specimen from Ternate (1897: 101), while in Edmunds' figure of zania (fig. 12 D) they are thin threads. The tip of the tentacles is black in Bergh's and Eliot's, and in the present animal, while it is white in Allan's and Edmunds' figures. This might be an easy distinctive character for future classifications. In a letter (7.XI. 1974) William Rudman suggested to distinguish the high specimens of Edmunds from the flattened one described by Joyce 
Allan (1947). The external difference of there light forms with dark rings is difficult to grasp; the black tips of the tentacles do not go conform to the height of the animals. Robert Burn (letter of 25. XII. 1974) supposes that there are several ringed forms, and pantherina belongs to this group.

Allan (1947: 654) and Risbec (1956:17) stress that it is impossible NOT to recognize funebris. However, from Risbec's description it appears that he had neither funebris nor zania, but a species of Peltodoris with unarmed penis and "vagina" He himself found it to be very similar to Peltodoris atromaculata (Bergh, 1880a: 45). Risbec's figure 20 of the notal papillae with spicules projecting on different levels, not around the tip, is very unlike the caryophyllidia of Edmunds' drawing (1971, fig. 12 B) and the present material. In Risbec's figure 21 the insemination duct enters and leaves the spermatocyst on opposite sides, while one branch of the insemination duct enters and leaves the spermatocyst in Jorunna funebris (Fig. 21).

Besides Jorunna funebris and zania there are many other whitish doridids with dark rings or spots, e. g., Discodoris maculosa (Cuv.) which has been synonymized with funebris, till Pruvot-Fol examined the type material $(1934 \mathrm{a}: 84 ; 1934 \mathrm{~b}: 220)$ and found that it belonged to Discodoris. Platydoris townsendi Eliot (1905: 253, pl. 5, fig. 4) is described as very similar to funebris. Kenny (1970: 89) supposes that Discodoris whitleyi Allan, 1932, is a synonym to funebris.

\section{Jorunna pantherina Angas, 1864}

Figures 22A-22C

Doris pantherina Angas, 1864: 47, pl. 4, fig. 5 Jorunna pantherina Thompson, 1975, in press (pl. I (h), (i); fig. 4).

Distribution. - Australia, New South Wales, Port Jackson and Sydney area. Intertidal and shallow sublitoral localities.

Material. - Australia, New South Wales, Long Reef, one specimen, II.1968, Thomas Everett Thompson leg.

Remarks and additions to Thompson's description. - The animals, living 8-22 $\mathrm{mm}$ in length, are described by Thompson (1975).

The salivary glands have inconspicuous glandular tubes and long muscular ducts. The oesophagus of the present animal loops forward before it passes through the nerve ring, as in some specimens of tomentosa and others. The stomach is free, not covered by the digestive gland. The intestinal epithelium is thrown into logitudinal folds.

The labial cuticle bears two areae of rodlets up to $0.04 \mathrm{~mm}$ long (Fig. $22 \mathrm{~A}$ ). The radula (Fig. $22 \mathrm{~B}$ ) has 20 rows of up to 5.14 .0 .14 .5 


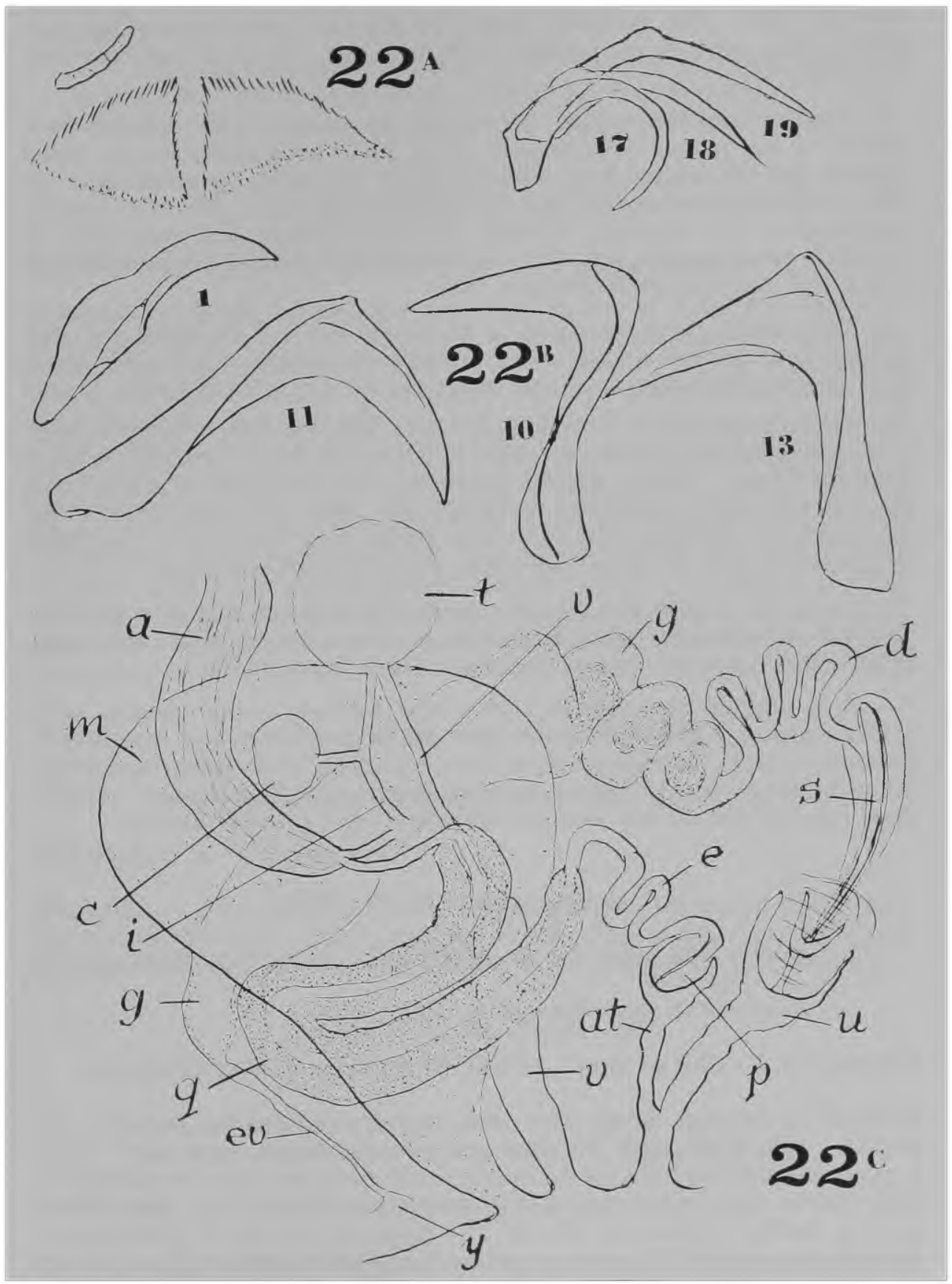

Figure 22 - Jorunna pantherina

22 A - Labial plates. 22 B - Radular teeth. $22 \mathrm{C}$ - Diagram of reproductive organs. 
teeth. The innermost (1) is a little broader than the following hooks $(10,11,13)$. The marginal teeth $(17-19)$ are more slender but not shorter than those in the middle of the half-row. They do not bear any denticles.

The reproductive organs correspond to those in the other known species of the genus. The ampulla (Fig. $22 \mathrm{C}$, a) divides into the inner oviduct and the sperm duct. The walls of the latter are thickened by high prostatic epithelium (q) and form a backward loop. Its ectal forward continuation, the muscular efferent duct (e), winds and ends with a roundish penial papilla $(\mathrm{p}), 0.2 \mathrm{~mm}$ in diameter, which projects into an about $1.0 \mathrm{~mm}$ long male atrimum (at).

The female gland mass $(\mathrm{m})$ is of normal size. The vagina (v) has a wide outer section and narrows towards the sperm vesicle. Its inner part and the spermatheca (t) and spermatocyst (c) were not seen.

The vestibulum $(\mathrm{u})$ is wide and longer than the male atrium, though it is contracted into transverse folds. Extended it would evidently be considerably longer. The vestibular gland (q) with its ental glandular and ectal secrete-storing sections is as in alisonae (Fig. 27) and others. The muscular duct (d) opens with a $0.66-0.70 \mathrm{~mm}$ long stylet (s). The ental connexion (ev) to the sinus (y) of the genital papilla was seen.

From the present key (p. 14) pantherina appears nearest related to spazzola and alisonae with quite short male atrium, and malcolmi and luisae in which the male duct opens in common with the vestibule.

It is difficult to judge the differences between similar species with scarce material, often of different ages and different states of contraction. However, I prefer to separate them, even with slight distinctive characteres, for geographic reasons, before lumping distant populations, and I knowingly run the risk of later authors synonymizing my "new" species.

\section{Jorunna gigas (Bergh, 1876)}

Kentrodoris gigas Bergh, 1876: 419, pl. 50, figs. 9-23, pl. 51, figs. $1-5$

Kentrodoris gigas Dawydoff, 1952: 110.

Distribution. - Gulf of Siam; Annam; Philippines; Central China Sea.

Remarks. - Bergh hardly ever indicated the differences between his species. His descriptions of gigas and annuligera are very much alike. J. gigas has dark blotches on the notum, while there are rings in annuligera. Both species have black tips of their pointed tentacles. The first lateral tooth is similiar in both (pl. 50, fig. 15: gigas; pl. 52, fig. 5: annuligera). All teeth are pointed. The outermost tooth is hook-shaped in gigas (pl. 50, fig. 21) and straight in annuligera (pl. 52, fig. 4). This last seems to be the only reliable difference between the species which originally came from the same locality, Aibukit. 


\section{? Doris inframaculata Abraham. 1877}

Doris inframaculata Abraham, 1877: 247, pl. 27, figs. 5-7 non Doris inframaculata Bergh, 1880a; $58=$ Platydoris

non Platydoris inframaculata Farran, 1905: 336, pl. 2, figs. 2-7, pl. 3 , figs. 8,9

? Kentrodoris inframaculata von Ihering, Risbec, 1928: 95, textfig. 17 ; pl. 3, fig. $7 ; 1930: 273$, figs. $10 \mathrm{~h}-\mathrm{n} ; 1953: 38$.

Distribution. - Ceylon; Amboina; New Caledonia, Noumea.

Remarks. - Risbec erroneously gave von Ihering as author of inframaculata and of infranaevata, the latter from the Mediterranean. Also this species was established by Abraham (1877: 248, pl. 27, fig. 8). Risbec considered infranaevata as a synonym of inframaculata and identified his New Caledonian material with the latter. Risbec's drawing of the notal papillae shows them as flat, blunt knobs with vertical spicules not projecting over the surface. He reports a radular formula of $30 \times 100$ and an unarmed penis, but does not mention a vestibular gland, nor does he figure a vestibular stylet (1930). The systematic position of his up to $150 \mathrm{~mm}$ long specimens is doubtful. Farran's figures of teeth and elements of penial spines and vaginal plates certainly belong to a Platydoris, "but it is impossible to decide with certainty upon the identity of closely allied species of Platydoris without an examination of the radula and the usually very characteristic armature of both penis and vagina" (Farran, 1905: 336).

\section{? Doris infranaevata Abraham, 1877}

Doris infranaevata Abraham, 1877: 248, pl. 27, fig. 8.

Distribution. - Mediterranean.

Remarks. - The specimen with 6 bipinnate gills measures $42 \times 28 \mathrm{~mm}$. The notum bears very minute granules, and the hyponotum, fine dark spots. Its generic position is uncertain, possibly it is synonymous to tomentosa.

\section{Jorunna ? atypha Bergh, 1881 Figure 21}

Jorunna ? atypha Bergh, 1881: 145, pl. J, figs. 22-25 Jorunna atypha Pruvot-Fol, 1954: 275, figs. 111a, b.

Distribution. - Mediterranean, Trieste, one specimen.

Remarks. - The notal tubercles are similar to those of Rostanga perspicillata (Bergh, 1881: 204, pl. J, fig. 2), so they are true caryophyllidia. The two outermost teeth are denticulate. The vestibular gland ("Stacheldrüse") is large, and there is a stylet in its outlet. Bergh did not succeed to find 
jaw rodlets in the badly preserved specimen. Bergh said: if it is a new species, it differs by the shape of its outermost teeth.

However, the shape of the tentacles (Fig. 21) is quite different from any of the described Jorunna. They are short, flat and broad. Bergh doubted whether this insufficiently described species really belongs to Jorunna.

\section{Kentrodoris ? labialis Eliot, 1908}

Kentrodoris labialis Eliot, 1908: 112

Kentrodoris labialis O’Donoghue, 1929: 816, fig. 225.

Distribution. - Red Sea.

Remarks. - The notal papillae are caryophyllidia. There are 8-10 long, slender, bipinnate gills in the living animal. It has labial rodlets and a radula of $20-24 \times 18.0 .18$ teeth, which are not denticulate. The innermost tooth differs slightly from the others. O'Donoghue observed rudimentary rhachidian plates (fig. 225, a). The verge (Eliot) is armed with a long, colourless, curved stylet enclosed in a special sheath, very similar to the stylet of Doris maculosa $=J$. funebris, from which it differs by labial rodlets. Eliot pondered the identity of his species with Doris setosa Pease, 1860, which Kay \& Young (1969: 196) placed in Thordisa due to its pectinate marginal teeth. They also synonymized Pease's Doris pilosa with setosa. On the other hand Lim \& Chou (1970: 104) considered Pease's setosa as Rostanga.

\section{? Kentrodoris nigra Risbec, 1928}

Kentrodoris nigra Risbec, 1928: 91, pl. 2, fig. 6; 1953: 37

Distribution. - New Caledonia.

Remarks. - The cup-shaped gills are a feature of Jorunna, but there are no further characters indicated to warrant the allotment to the Kentrodoridae.

\section{? Kentrodoris pseudofusca Risbec, 1928}

Kentrodoris pseudofusca, Risbec, 1928: 92, textfig. 16, pl. 3, fig. 3 ; 1953: 37, fig. 12

Distribution. - New Caledonia.

Remarks. - The number of radular teeth, $30 \times 180$, is very high. The penis is unarmed, and a vestibular gland is not mentioned. Hoffmann 
(1938: 919) doubts whether pseudofusca is a Kentrodoris, because of the strange glands of the buccal tube (Risbec, 1928, fig. 16, 3, g). I found similar glands (in press) on the buccal tube of Peltodoris hummelincki igla Marcus (1967).

Jorunna spec. Pruvot-Fol, 1953

Jorunna sp., Pruvot-Fol, 1953: 78.

Distribution. - Atlantic coast of Morocco, Dakar.

Remarks. - The 8-9 tripinnate gills, no labial rodlets, distinguish the $42 \mathrm{~mm}$-long animal from luisae and malcolmi, and approach it to tomentosa. However, the reproductive organs could not be studied, so that its generic position remains uncertain.

\section{$7 \quad$ Jorunna spazzola (Marcus, 1955) \\ Figures 23-26}

Awuka spazzola Marcus, 1955: 156, figs. 180-192; 1958: 57, 1964: 199; 1970c: 210

Distribution. - Brasil, from Cabo Frio to Cananéia.

Material. - Brasil, São Paulo, Ilha do Cardoso near Cananéia, Bahia de Trapandé, under stone near low water-line, 24. I. 1974, one specimen.

Anatomical notes. - A re-examination of the original material and the serial sections as well as an analysis of the later specimens show that the species belongs to Jorunna. The colour of the slugs varies, the living animal (Fig. 23) was $12 \mathrm{~mm}$ long, a delicate grey with a few black spots near the borders of the notum and more numerous smaller spots all over. The general grey colour is brought about by single melanophores in the skin of the back, the rhinophores, and the stalks of the caryophyllidia, less numerous ones on the sides and on the gills. The sole is white. The anterior border of the foot is bilabiate, its upper lip deeply notched.

In the present animal which was larger than the first the spicules attain about $0.4 \mathrm{~mm}$ in length in the caryophyllidia, where their diameter is $0.018 \mathrm{~mm}$; in the skin they are smaller.

At first I considered my new animal as representing a new species. As it came from the same locality as some previous ones, classified as Awuka spazzola, I compared it carefully and found the gills of the 6 available specimens so far variable in number and shape, that they were evidently conspecific. The smallest slug, $5 \times 2.5 \mathrm{~mm}$, has 9 uni- to bipinnate gills united by a membrane around them up to one quarter of their height. In another animal, $6 \times 2 \mathrm{~mm}$, there were 7 uni- to bipinnate gills united up to half of their length. The greatest number were 10 bipinnate 

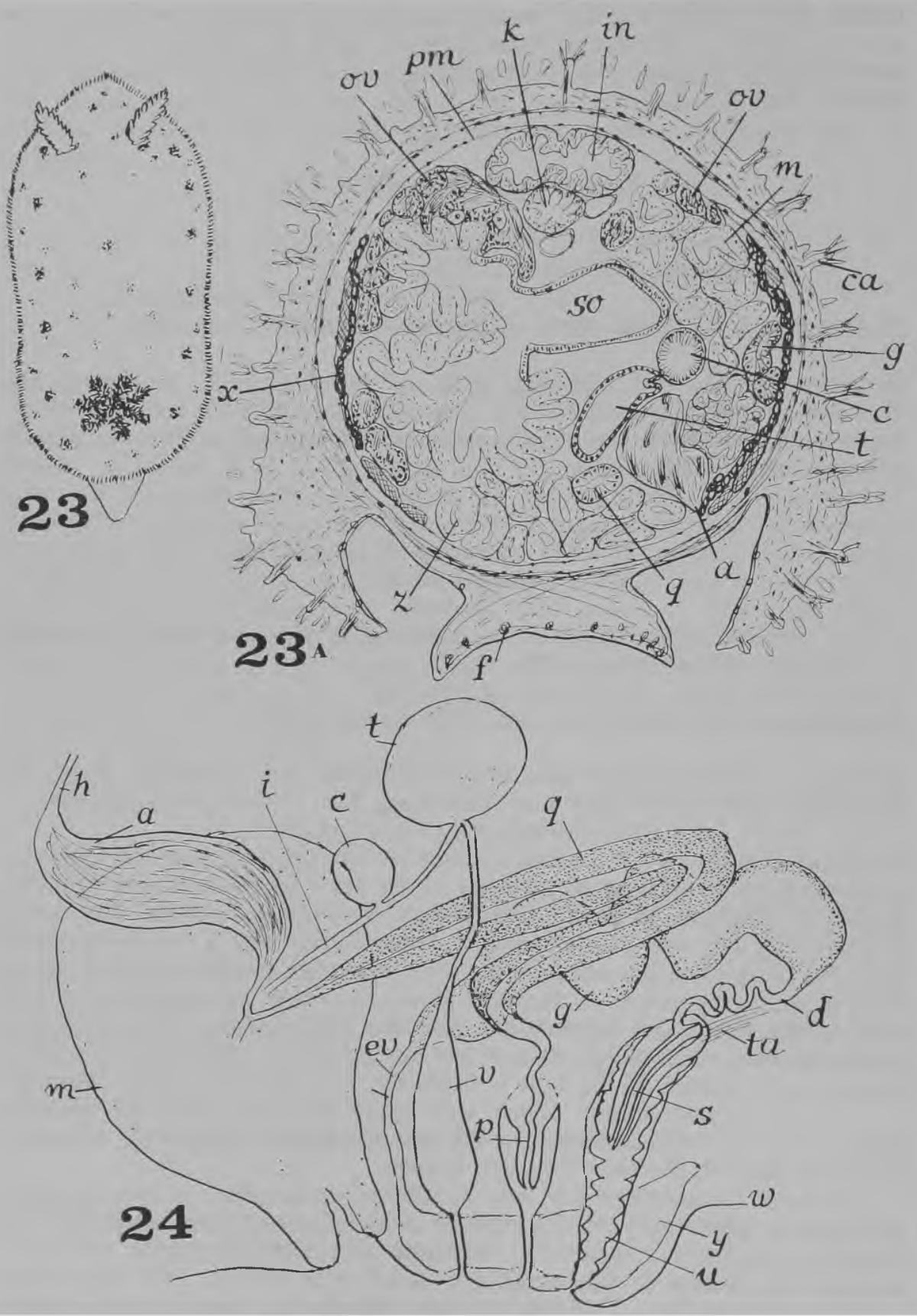

Figures 23, 23 A, 24 - Jorunna spazzola

23 - Dorsal view of living slug; from Fujichrome taken by Ian R. Ball. 23 A Transverse section to show pericardial glands (x). $24-$ Diagram of reproductive organs, reconstruction. 
gills, free to the roots, in a $9 \times 3.5 \mathrm{~mm}$ slug. The largest one, $10 \times 7 \mathrm{~mm}$, has 8 free, bi- to tripinnate gills.

In the labial cuticle there are two areae of blunt rodlets, up to $0.04 \mathrm{~mm}$ long. The radula has 19 rows of 16-17 laterals on either side of the naked rhachis. The hamate teeth are small near the rhachis, the innermost may have a small denticle. It was $0.07 \mathrm{~mm}$ high. The teeth increase to $0115 \mathrm{~mm}$ in the middle of the half-row and decrease outward. The five marginal ones measure $0.06-0.046 \mathrm{~mm}$. Several of the outermost teeth may have prongs or irregular denticles.

The reproductive organs (Fig. 24) correspond to those of the other species of the genus. The ampulla (a) divides into the male and female branches. The former widens to a glandular prostatic loop (q) and passes as a thin muscular duct into the penial papilla (p) $0.16-2 \mathrm{~mm}$ long.

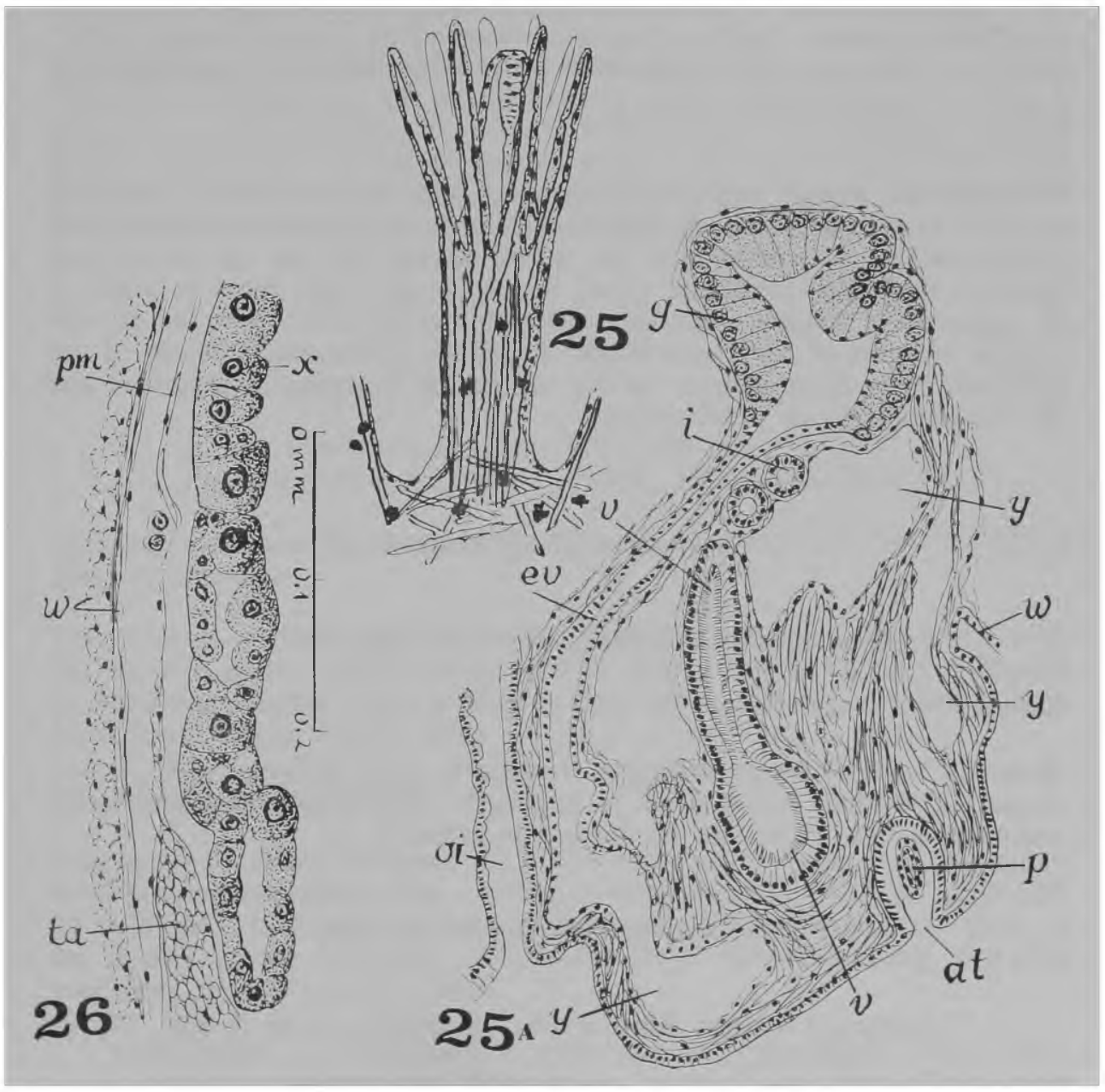

Figures 25, 25 A, 26 - Jorunna spazzola

25 - Clarified caryophyllidium with spicules and melanophores. $25 \mathrm{~A}$ - Section of vestibualr gland and its ental duct. 26 - Section of the pericardial gland. 
The latter is unarmed and projects with a slender tip into the male atrium, opening on the genital papilla. This refers to partly everted organs. The female branch leads into the big albumen and mucus glands $(\mathrm{m})$, whose outlet is wide and folded. The vagina (v) has a narrow entrance. After passing through the body wall it widens suddenly and then narrows gradually till it enters the spermatheca $(t)$. The insemination duct (i) leaves immediately beside this inlet and passes to the gland mass, taking up a short duct from the spermatocyst (c).

The wavy vestibular gland (g) is emptied through a thin, coiled duct (d) that leads to the muscular papilla projecting into the vestibule. In the papilla a $0.55 \mathrm{~mm}$ long cuticular stylet (s) is lodged. The vestibule (u) forms the fourth outlet on the genital papilla. The ental end of the vestibular gland is prolonged into a thin epithelial canal (Fig. 25A, ev), which dissappears in a wide sinus (y) around the ducts opening through the genital papilla. Such a duct was observed by Kay \& Young (1969: $185)$ in J. alisonae, and by Edmunds $(1971: 364,368)$ in J. malcolmi and J. zania. The pericardial glands (Figs. 23A, 26, x) are described in the last chapter (p. 59).

Remarks. - Awuka was one of the first doridids we studied, and so I incurred to the same error that had occurred to Bergh with his Kentrodoris (1876-1905). I thought that the stylet always had to be penial, and included the coiled vestibular gland in the female gland mass to which it is apposed. I assume the full responsibility for this error, as it was always my part of our "team work" to do the anatomical analysis of our material, while Ernst Marcus mostly did the bibliographic comparison and the redaction of our publications.

\section{? Jorunna marchadi Risbec, 1956}

Jorunna marchadi Risbec, 1956: 16, figs. 54-57

Distribution. - Vietnam.

Remarks. - The notum is ridged irregularly as in Halgerda and Asteronotus. The long, coiled penis is unarmed. The vestibular gland has a chitinous axis. There are no further indications.

non Jorunna hartleyi (Burn, 1958)

Rostanga hartleyi Burn, 1958: 28, textfig. 5, pl. 2, figs. 12, 13; 1969: 82

Jorunna hartleyi Burn, 1962: 163, figs. 15, 16

Distribution. - Australia, Victoria. 
Remarks. - In letters of 12.III. and 25.XII.1974 Robert Burn himself is doubtful of the generic position of his hartleyi, as the species is very rare, and of the uniformity of his material. If the first figure of the radula belongs to that species, the denticles of the laterals do not fit into Jorunna. The figure 16 of the genital organs refers, according to the letter, to J. pantherina, but contrary to Thompson's statement (1975, in press), the vestibular gland has no stylet. So the species figured is no Jorunna, probably a Rostanga.

Kentrodoris (?) sp. Burn, 1966

Kentrodoris (?) sp. Burn, 1966: 275

Distribution. - Australia, Victoria, Lonsdale.

Remarks. - In his letter of 25.XII.1974 Robert Burn writes: "it is a small southeastern Australian species with brown purple spots and rings. Its stylet has been noted in use during copulation" These indications are not sufficient for a determination of the generic position.

8. Jorunna alisonae, spec. nov.

Figure 27 A-G

Joruna tomentosa Young, 1967: 168

Jorunna tomentosa Kay \& Young, 1969: 184, figs. 11, 17

Material. - Three specimens from Hawaii, by favour of Prof. E. Alison Kay, Honolulu.

Distribution. - Pacific, ? Eniwetok; Hawaiian Islands, Oahu and Kauai. On rocks in shallow waters shoreward of reefs. Kay \& Young's indication of Australia possibly refers to Allan's description of Jorunna funebris from New South Wales (1947: 454).

Holotype: USNM 710701

Diagnosis. - Small Jorunna, 4-12 mm long; notum with caryophyllidia; 5-15 bi- and tripinnate gills. Labial rodlets present. Radula 14-20x2024.0.20-24. Innermost and outermost teeth a little shorter than those in the middle of the half-row. Vestibular stylet lodged in long, eversible vestibule. Penial papilla minute.

Description. - The studied specimens are, preserved, $9 \mathrm{~mm}$ long, $5 \mathrm{~mm}$ broad and $4 \mathrm{~mm}$ high, $8 \times 6 \times 4 \mathrm{~mm}$, and $6 \times 3.2 \times 3 \mathrm{~mm}$. The notum stands out over the foot on all sides. The animals are whitish, stippled with brown or black chromatophores on the back, in the caryophyllidia, 
and in the peritoneum. In one specimen there are pigmentfree areae on both sides. The under side is white.

The rhinophores have about 10 foliations. The tentacles are pointed. The upper lip of the bilabiate anterior border of the foot is notched. There are 9 to 15 gills. In the preserved, contracted specimens they appear uni- to bipinnate, but are in life probably branched farther. The branchial glands are small.

The labial cuticle bears two areae of up to $0.035 \mathrm{~mm}$ high rodlets, the shape of which is different (Fig. 27 A, B).

The radula has 14-20 rows with a naked rhachis and 20-24 lateral teeth per half-row. The innermost tooth (Fig. $27 \mathrm{C}$ ) is a little broader than the following ones. These are hook-shaped; the longest are $0.12 \mathrm{~mm}$ high (Fig. 27 D). One to 4-5 marginal teeth are slender with a quite short base, decreasing in length, and sometimes bearing a denticle near

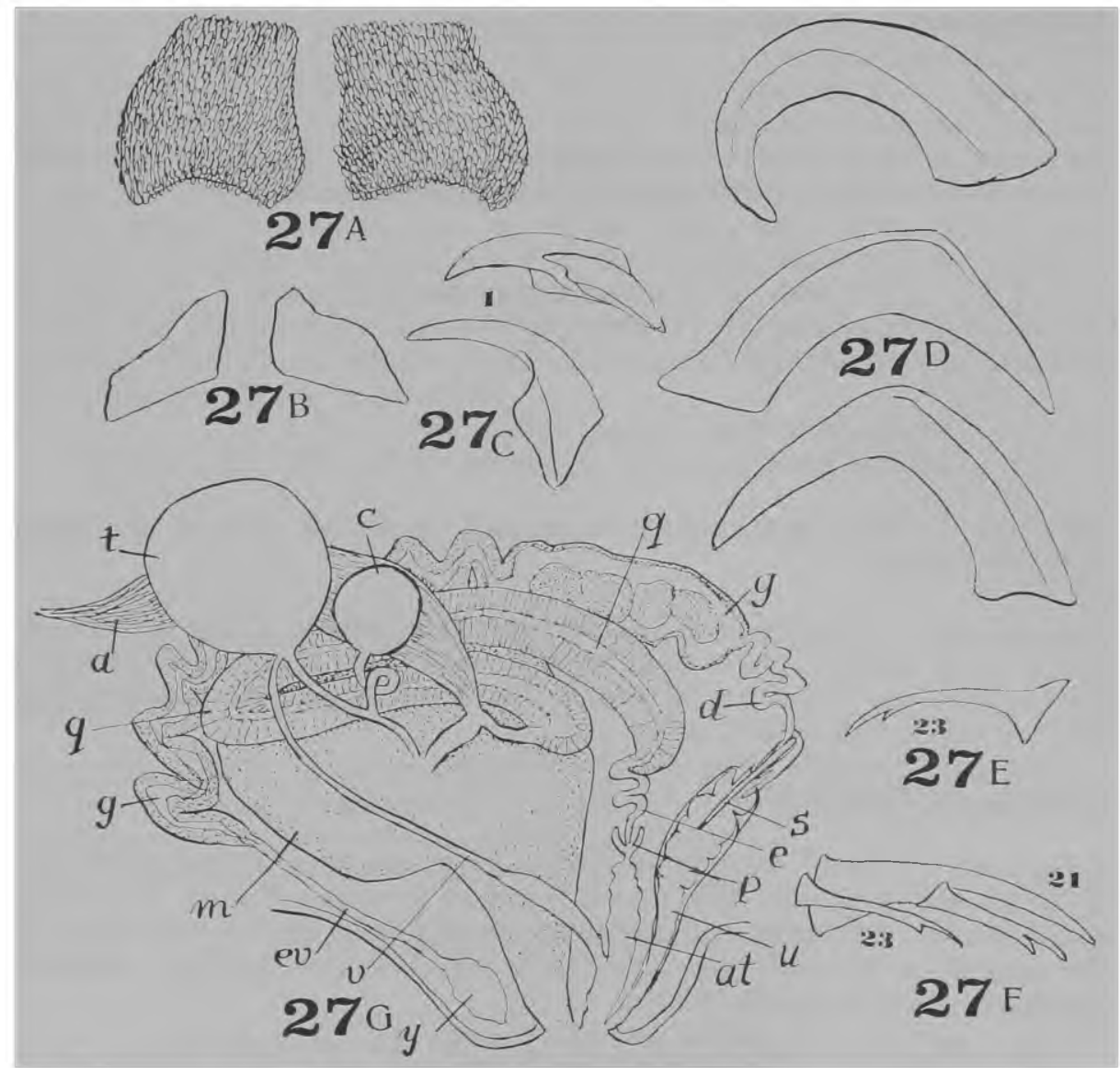

Figure 27 - Jorunna alisonae

A - Areae of labial rodlets. B - same of other specimen. C - Two first lateral teeth of radula. D - Three teeth from middle of half-row. E - Marginal tooth. $\mathrm{F}$ - Malformed marginal teeth. G - Diagram of reproductive organs. 
the tip (Fig. 27 E). One row of outermost teeth was malformed, the second tooth originating half way up the third tooth (Fig. $27 \mathrm{~F}$ ).

The male duct leaving the ampulla (Fig. $27 \mathrm{G}, \mathrm{q}$ ) is lined with a high prostatic epithelium. It runs straight backward, bends upon itself and is continued by a coiled muscular efferent duct, which opens with a $0.06 \mathrm{~mm}$ long papilla into the male atrium.

The ovotestes lie on the dorsal side of the digestive gland. The sectioned specimen was in female phase, and a number of eggs lie in the oviduct and its widening in the female gland mass. The latter is composed of differently staining gland cells in separate sections.

The narrow vagina (Fig. $27 \mathrm{G}$; v) goes out from a common atrium shared with the male atrium, and courses to the spermatheca (t) lying on the left side of the oesophagus. The insemination duct gives a small branch to the spermatocyst (c) and enters the gland mass (m).

The ental part of the vestibular gland $(\mathrm{g})$ has a $0.025-0.045 \mathrm{~mm}$ high epithelium. In the ectal part this is only $0.01-0.012 \mathrm{~mm}$ high, and the wide lumen contains lumps of coagulated secretion. The outlet is a narrow winding muscular duct which opens into the sheath of a $0.7 \mathrm{~mm}$ long stylet, projecting into the vestibule. In retracted state the vestibule (u) measures $2.3 \mathrm{~mm}$.

Kay \& Young discovered a connexion from the ental end of the vestibular gland to the female gland mass. The duct is present also in J. malcolmi and J. spazzola. In the latter and also in the sections of alisonae it was found to open, not into the female gland mass, but into a sinus which surrounds the outlets of the genital ducts on the tip of the genital papilla (Fig. $25 \mathrm{~A}$, ev). Where the duct enters the sinus, the epithel flattens and becomes unrecognizable.

Discussion. - Kay \& Young assumed that J. tomentosa occurs throughout the world, and so did Edmunds. However, their description contains minute differences which permitted me to distinguish their form from the European tomentosa, and the examination of the specimens confirmed their findings. Both the Hawaiian and the African species have labial rodlets contrary to tomentosa. In the Hawaiian species the vestibule is much longer that the vestibular stylet. In the African ones it is of the same length. The Hawaiian species has a minute penial papilla, while none was figured for the African specimens.

The specific name is chosen in honour of Prof. Dr. E. Alison Kay, University of Honolulu, Hawaii.

9. Jorunna malcolmi, spec. nov.

Figures 28-30

Jorunna tomentosa Edmunds, 1971: 364, figs. 11A-11G.

Distribution. - Indian Ocean, Tanzania; Atlantic, Ghana, Tema.

Holotype: Brit. Mus. N. H. 19752W 
Diagnosis. - Jorunna with caryophyllidia, labial rodlets, undifferentiated marginal teeth of thie radula, no penial papilla, a vestibular stylet as long as the vestibule enclosing it.

Remarks. - Dr. Malcolm Edmunds kindly sent me his sketches and notes as well as a specimen each of his Tanzanian and Ghana samples. Unfortunately the specimens were both injured just in the decisive region, the common atrium with the openings of the ejaculatory duct and the vestibular gland with its stylet. For my description I rely upon the careful observations and drawings of Edmunds (Figs. 28-30).

The animals from Ghana were $32-40 \mathrm{~mm}$ long alive. They have up to 20 rhinophoral leaflets, and the large specimens, 11 tripinnate gills. The notal papillae are true caryophyllidia. The notum is yellowish brown with two rows of dark spots along the sides, or irregularly distributed ones. The tentacles are finger-shaped.

The lips bear two areae of rodlets (Edmunds, fig. $11 \mathrm{G}$ ). The radular formula is $23 \times 24$ to $30 \times 26$. Only one or two outermost teeth are rudimentary and differ from the rest by a short base and a straight cusp (1 c., fig. $11 \mathrm{E}, 30)$. The stomach is covered by the digestive gland.

Edmunds had two further slugs of 3 and $6 \mathrm{~mm}$ length, golden yellow with brown spots and white marks. The prostate of the large ones has a cream-colored proximal and a brown distal region.

The vestibular gland has a light ental and a dark ectal part. The latter contains coagulated brown secretions. As in J. spazzola and J. alisonae the ental end of the vestibular gland is continued into a narrow duct, which Edmunds described as opening into the female mass.

Discussion. - Edmunds as well as Young (1967: 168) and Kay \& Young (1969: 184, figs. 11, 17) considered their materials from the Pacific, Hawaiian Islands and Eniwetok, and from Africa, as tomentosa, and tomentosa as cosmopolitan. The references to tomentosa by Young (1969: 423, 427, 430) deal with the European species. The Pacific J. alisonae differ from J. malcolmi both from Tanzania (Fig. 28) and from Ghana (Fig. 30) by the shape of its outermost tooth, and by its vestibule much longer than the vestibular stylet. It also has a minute penial papilla (Fig. $11 \mathrm{~A}$, ed), which is completely absent in Edmunds' exact drawings (Fig. 28 (copied from 1971, fig. 11, F) and Fig. 30, original drawing by Edmunds).

I consider Edmunds' species from Tanzania and from Ghana as a distinct new species and dedicate it to the meritorious Scientist Malcolm Edmunds.

Figures 28-30 - Jorunna malcolmi

28 - Diagram of reproductive organs of animal from Tanzania, slightly modified from Edmunds (1971, fig. 11 F). 29 - Teeth of specimen from Ghana, last lateral and two marginals, and one marginal from another row, drawn by Malcolm Edmunds. 30 - Diagram of reproductive organs of animal from Ghana, drawing by Malcolm Edmunds. 


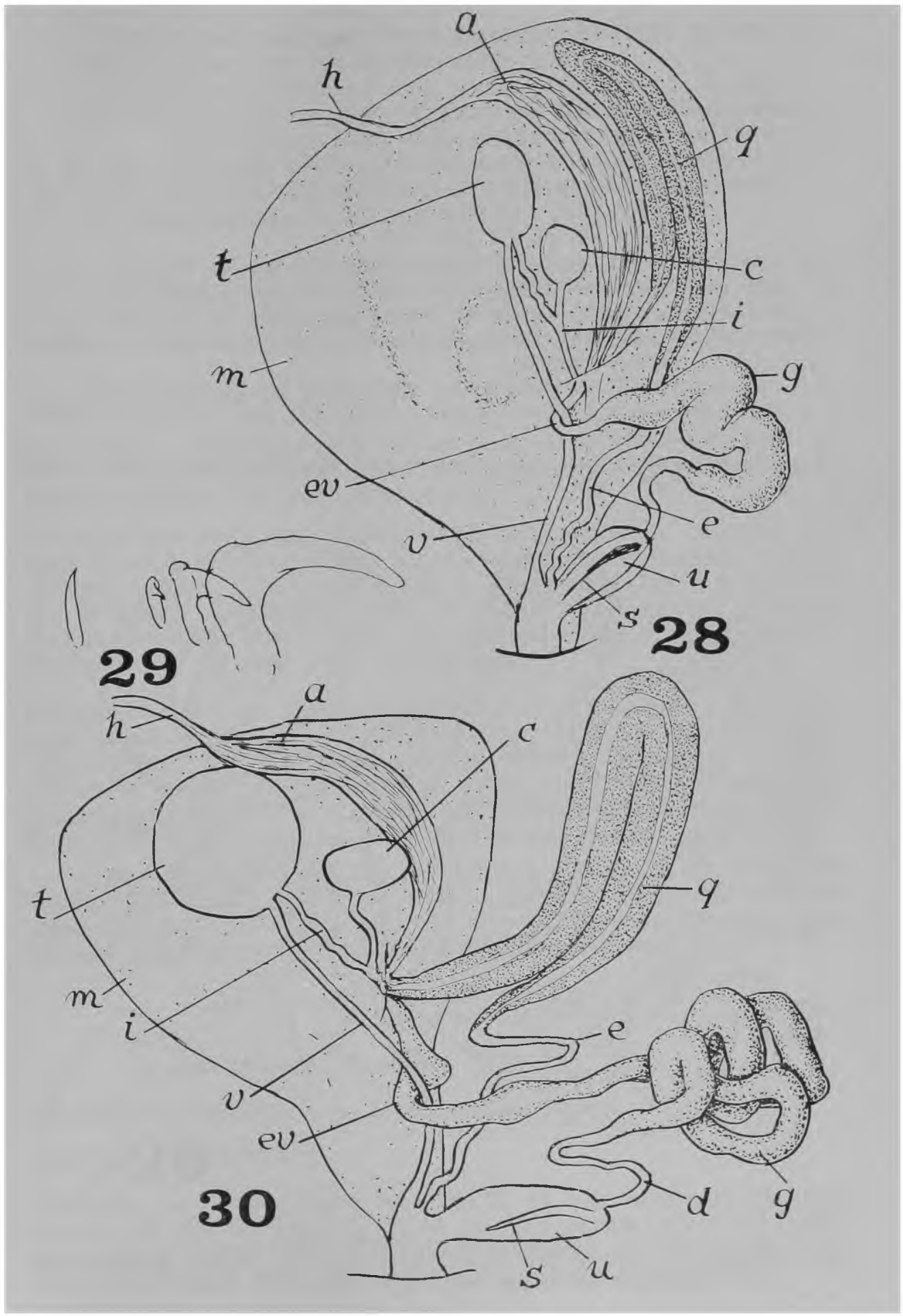


10. Jorunna zania, spec. nov.

Figures 31, 32

non Doris maculosa Cuvier, 1804: 466

non Doris funebris Kelaart, 1859: 293

? Doris funebris Alder \& Hancock, 1864: 122, pl. 30, figs. 9, 10 non Kentrodoris annuligera, Bergh 1876: 423, pl. 52, figs. 3-16; 1875, pl. 41, fig. 1; 1890: 923, pl. 85, fig. 8, pl. 89, fig. 32; 1897: 98, pl. 12, figs. 1-6

non Kentrodoris maculosa Bergh, 1897: 98, pl. 12, fig. 6 non Kentrodoris maculosa Eliot, 1906: 649, 1001; 1907: 85 non Doris funebris Kelaart, O'Donoghue, 1933: 222, pl. 19 non Doris maculosa Cuvier, Pruvot-Fol, 1934b: 220-223 = Discodoris maculosa

? Kentrodoris funebris Allan, 1947: 454, pl. 43, figs. 10-12 non Kentrodoris funebris Risbec, 1956: 17, figs. 18-22; = Peltodoris?

? Kentodoris (err. pro Kentrodoris) funebris Kenny, 1960: 226; 1970: 88

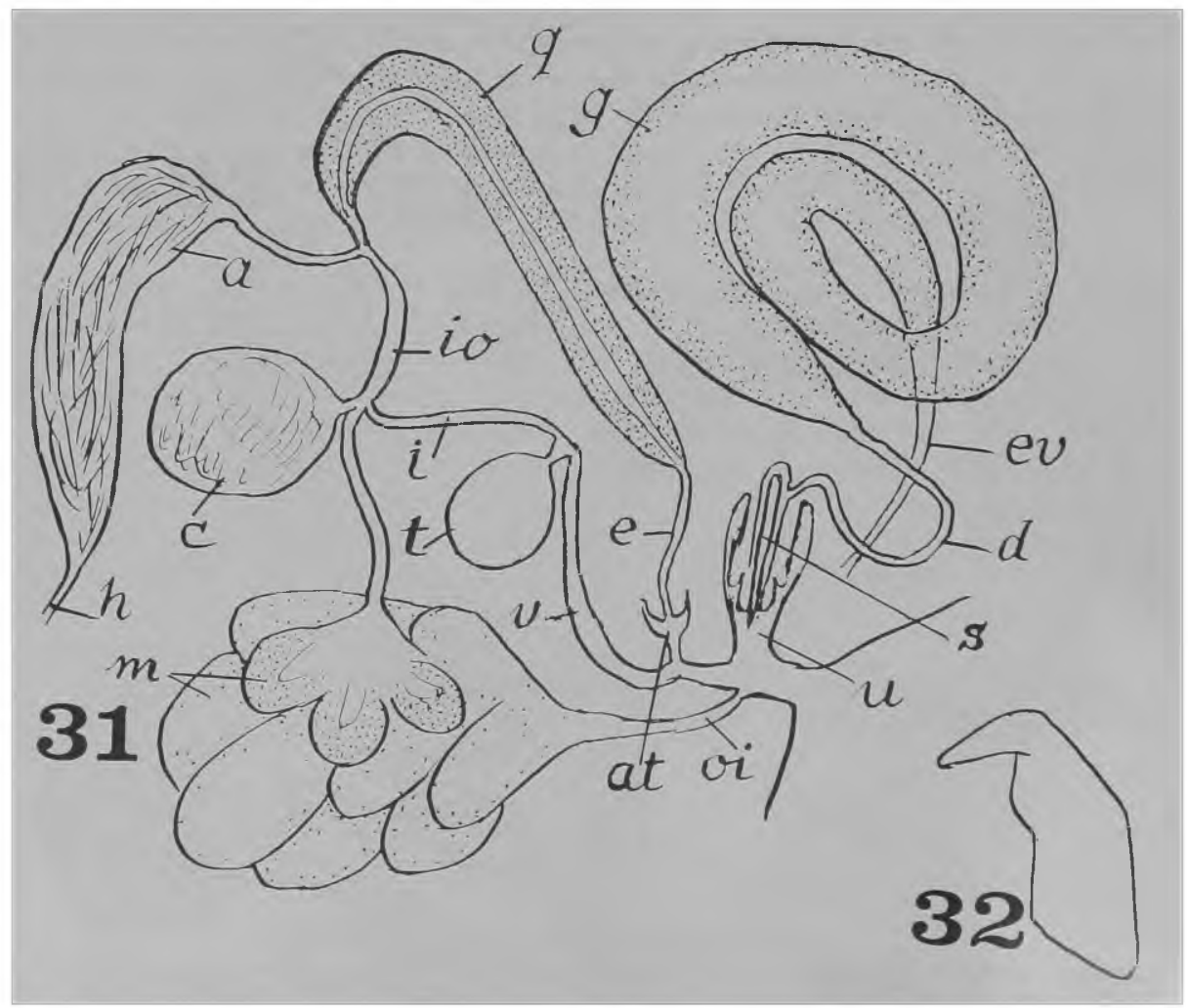

Figures 31, 32 - Jorunna zania

31 - Diagram of reproductive organs, from Tanzania, slightly modified from Edmunds (1971, fig. 13). 32 - First lateral tooth. 
? Kentrodoris annuligera Engel \& van Eeken, 1962: 25, figs. 2, 3 non Kentrodoris funebris Marcus, 1965: 276

? Kentrodoris maculosa Guang Yu \& Si, 1965: 11, pl. 3, fig. 6 non Discodoris sp. Lim \& Chou, 1970: 99, 104; = Discodoris annuligera (Bergh $1876=$ Kentrodoris annuligera); figs. $1 \mathrm{~F}$, $3 \mathrm{~L}, 7 \mathrm{~A}, 7 \mathrm{~B}$; it is a Discodoris by reason of its jaw plates, fig. 1 A, probably Discodoris maculosa (Cuvier, 1804)

+ Kentrodoris funebris Edmunds, 1971: 366, figs. 12, 13

Distribution. - Western Indian Ocean, Tanzania, Dar-es-Salaam. For the records marked with ? it remains doubtful, whether they refer to funebris Kelaart = annuligera Bergh, or to the present species, or even to none of both. Burn suspects there should be still more ringed species.

Holotype: Brit. Mus N. H. 197547

Diagnosis. - Jorunna, around $26 \mathrm{~mm}$ long, body white with black or blackish red spots and circles, notum with caryophyllidia, rhinophores with about 20 leaflets, 5 bi- and tripinnate gills.

Tentacles with white tips. Labial cuticle without rodlets. Radular formula $19 \times 20.0 .20$. Teeth simply hamate, innermost and outermost slightly different in shape. The outermost one or two sometimes have a few needlelike serrations. The penial papilla is minute. The vestibule is longer than the vestibular stylet. From the ental end of the vestibular gland a duct goes into the sinus of the genital papilla.

Remarks. - For the full description I refer to Edmunds' paper. The penial papilla is big and bulbiform in funebris, (Fig. 21) minute in zania (Fig. 31, p). The vestibule is probably longer in funebris, it is partly everted in the figure of zania. The cutilar stylet, $0.8 \mathrm{~mm}$ long in a specimen of funebris of similar size, is $0.34 \mathrm{~mm}$ in the present specimen. Both funebris and zania have black spots on their notched upper lip.

I give a modified diagram of Edmunds' figure $13 \mathrm{~B}$, where the vestibule is drawn in an everting phase. Edmunds' interpretation of the sperm vesicles on the vaginal duct was derived from serial sections. I am not sure whether it will be confirmed by future observers.

11 Jorunna luisae, spec. nov.

Figures $33-46$

Jorunna tomentosa Schmekel, 1968: 115, 148

Material and Distribution. - Mediterranean, Naples.

Holotype: USNM 710702

Diagnosis. - Small Jorunna, alive up to $14 \mathrm{~mm}$, with caryophyllidia, rhinophores with 12-14 leaflets, 10-12 uni- to bipinnate gills, labial rodlets short, radula 15-20x13-20, 3-6 marginals sometimes irregularly denticulate. Penial papilla well developed. Vestibular stylet $0.3-0.64 \mathrm{~mm}$ long. 

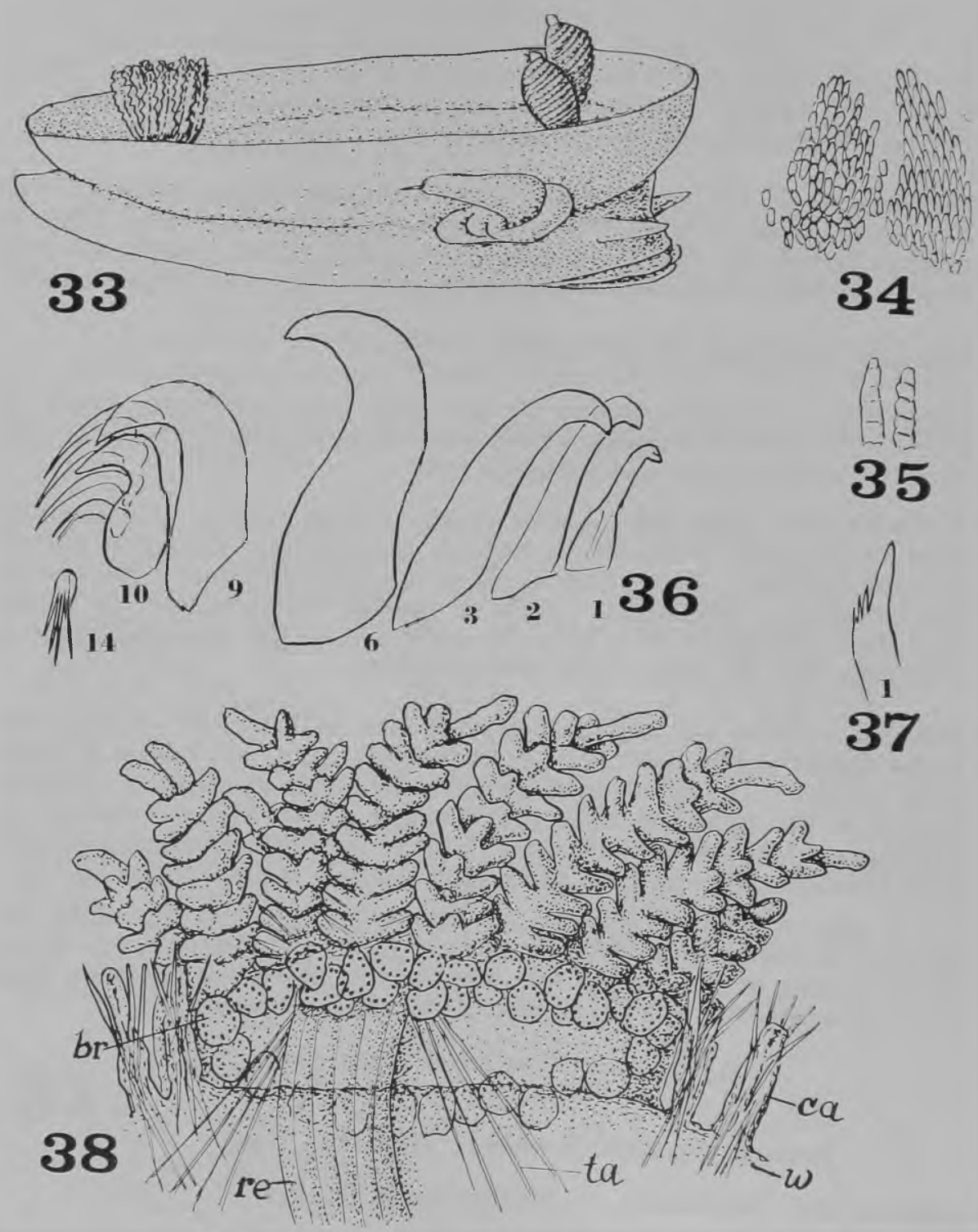

Figures 33-38 - Jorunna luisae

33 - Preserved specimen. $34-$ Labial areae. $35-$ Labial rodlets. 36 - Radular teeth. 37 - First tooth with exceptional prongs. 38 - Gills and branchial glands
from clarified preparation. 
Description. - The 10 preserved specimens, five of which were dissected (Bergh always wrote "sacrificed"), were up to $10,5 \mathrm{~mm}$ long. Alive the largest had measured $14 \mathrm{~mm}$. Their colour is whitish. In life Luise Schmekel described them as whitish, light cadmium yellow to orange and raw sienna. On each side of the notum is a row of a few brown spots. In some specimens scattered stipples all over the notum are preserved.

The notal tubercles are true caryophyllidia of up to $0.2 \mathrm{~mm}$ height, smaller towards the borders of the notum, whith spicules projecting up to $0.1 \mathrm{~mm}$ around the central, sensitive knob. The largest caryophyllidia are located in the middle of the notum, on the borders of the branchial pocket and around the rhinophoral pits.

The short-stalked rhinophoral clubs have 12-14 leaflets and a small terminal knob (Fig. 33). The small tentacles are conical and pointed. The bilabiate anterior border of the foot has a deeply notched upper lip. The hind end of the foot is pointed. There are 10-12 uni- to bipinnate gills with numerous globular glands at their roots (Fig. 38).

The labial cuticle is colourless or light brown. It is thrown into many longitudinal folds and bears two small areae of short polygonal rodlets, longer near the hind end (Fig. 34), formed of irregular layers (Fig. 35).

The radula (Fig. 36) is colourless, or the newest rows are light brown. The formula is $15-20 \times 3-6.10-14.0 .10-14.3-6$. The first lateral is more delicate than the following ones. On the inner side of the main cusp there is sometimes a prominence or a small denticle. The main part of the half-row has normal, hook-shaped teeth, whose basal part is about $0.11 \mathrm{~mm}$ long, the cusp, $0.082 \mathrm{~mm}$. Three to six outermost teeth are more slender, and their cusp, about $0.06 \mathrm{~mm}$, is straight. The outermost tooth has sometimes 1-4 fine prongs of almost equal length (Fig. 36).

The anterior blood gland lies over the cerebral ganglia, the posterior one, over the oesophagus. The oesophagus, after leaving the pharynx over the buccal ganglia, runs backward and bends forward again to pass through the nerve ring over the pedal comissure. The broad salivary glands lie far backwards over the digestive gland and are connected with their outlets into the pharynx by long and thin muscular tubes. These tubes are asymmetrical and show vestiges of torsion.

The wide stomach is embedded in the digestive gland. To its left the tip of the caecum appears on the surface of the liver. The walls of the stomach are thrown into longitudinal folds which are continued into the intestine. This leaves the stomach on its anterior face, curves dorsally to the right and runs straight to the anal opening in the centre of the circle of the gills.

The ovotestis covers the digestive gland. The hermaphrodite duct forms a distended ampulla (Fig. 39, a), which opens into the female gland $(\mathrm{m})$, whence the male duct emerges, immediately widening into a big prostatic part (q). This runs backward and bends forward upon 
itself, continued into a narrow winding efferent duct (e), which ends in a penial papilla $(p)$ projecting into the male atrium. The shape of the papilla varies according to the degree of its contraction; if relaxed, it is conical (Fig. 41), like Bergh's figure 9 (1880; not explained in the text, p. 51). Contracted it is globular (Fig. 43), then it resembles what Bergh thought to be the papilla of the vestibular gland $(1876 ; 422,427$, pl. 51, fig. 4, pl. 52, fig. 14). The penial papilla does not bear any stylet. The male atrium (at) lodging the penial papilla opens into a common atrium together with the wide entrance of the vagina (Fig. 40, v).

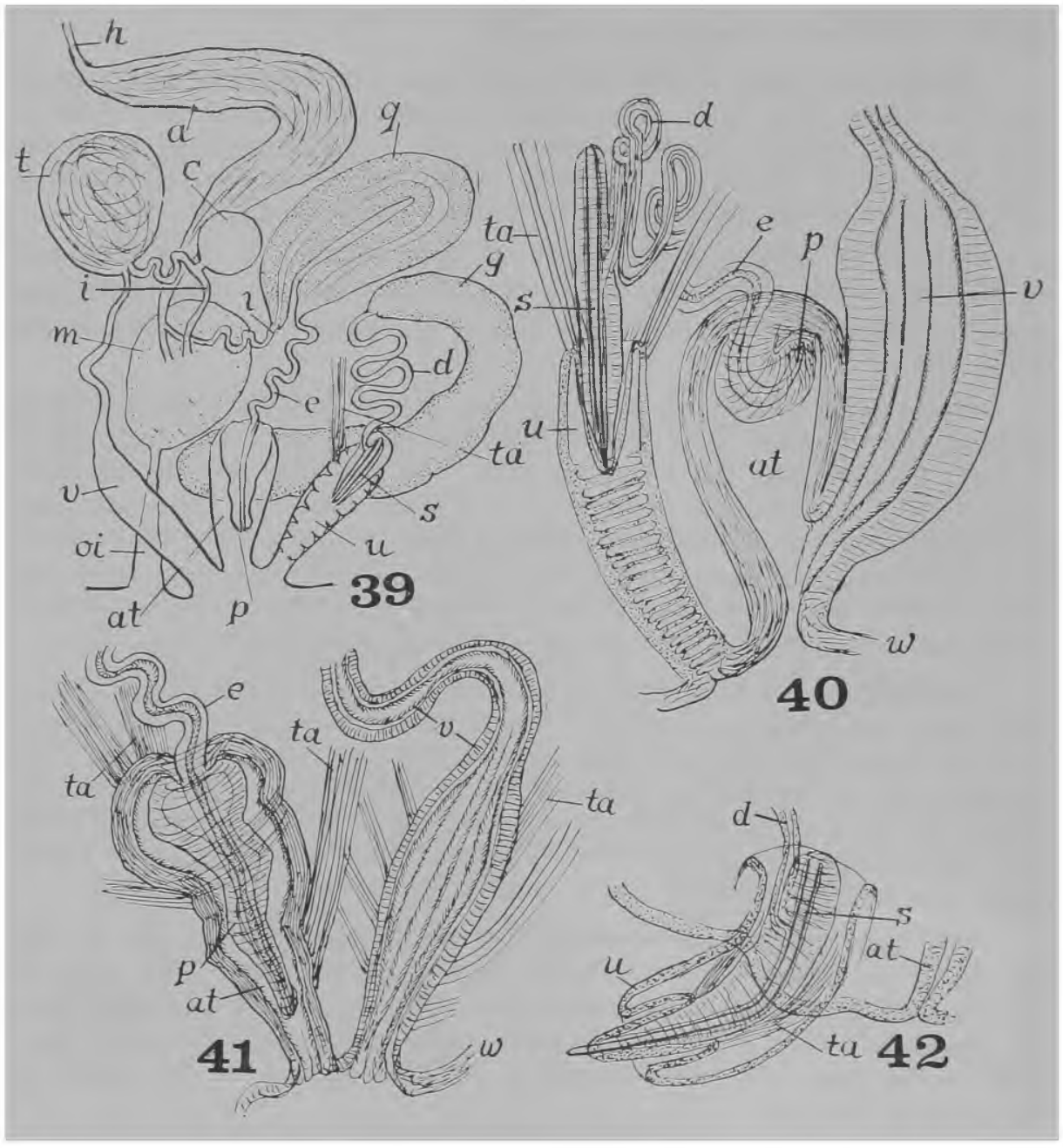

Figures $39-42$ - Jorunna tuisae

39 - Diagram of reproductive organs. 40 - Vagina, male atrium with retracted penial papilla, and vestibule with retracted stylet. 41 - Vagina and male atrium with protracted penial papilla. 42 - Vestibule with partly everted stylet. 
The female gland mass $(\mathrm{m})$ is very small, smaller than the prostatic duct, in the Naples specimens, about $0.5 \times 0.4 \mathrm{~mm}$, that is $6-7 \%$ of the body length. Nevertheless, the filled spermathecae and spermatocysts are a sign that the animals had already copulated, and Dr. Schmekel kindly informed, that she had obtained egg strings from them.

The wide outer oviduct opens into the common atrium when the organs are contracted. In evaginated state the opening lies in a collarlike fold formed by the common atrium around the papilla of the vestibular gland (Fig. 43). The vagina (v) going inward from the common atrium is at first a wide sac with longitudinally folded ciliated epithelium (Fig. 41). Farther inwards it narrows, and this slender tube enters the spermatheca $(t)$, globular in the small Neapolitan animals, and containing

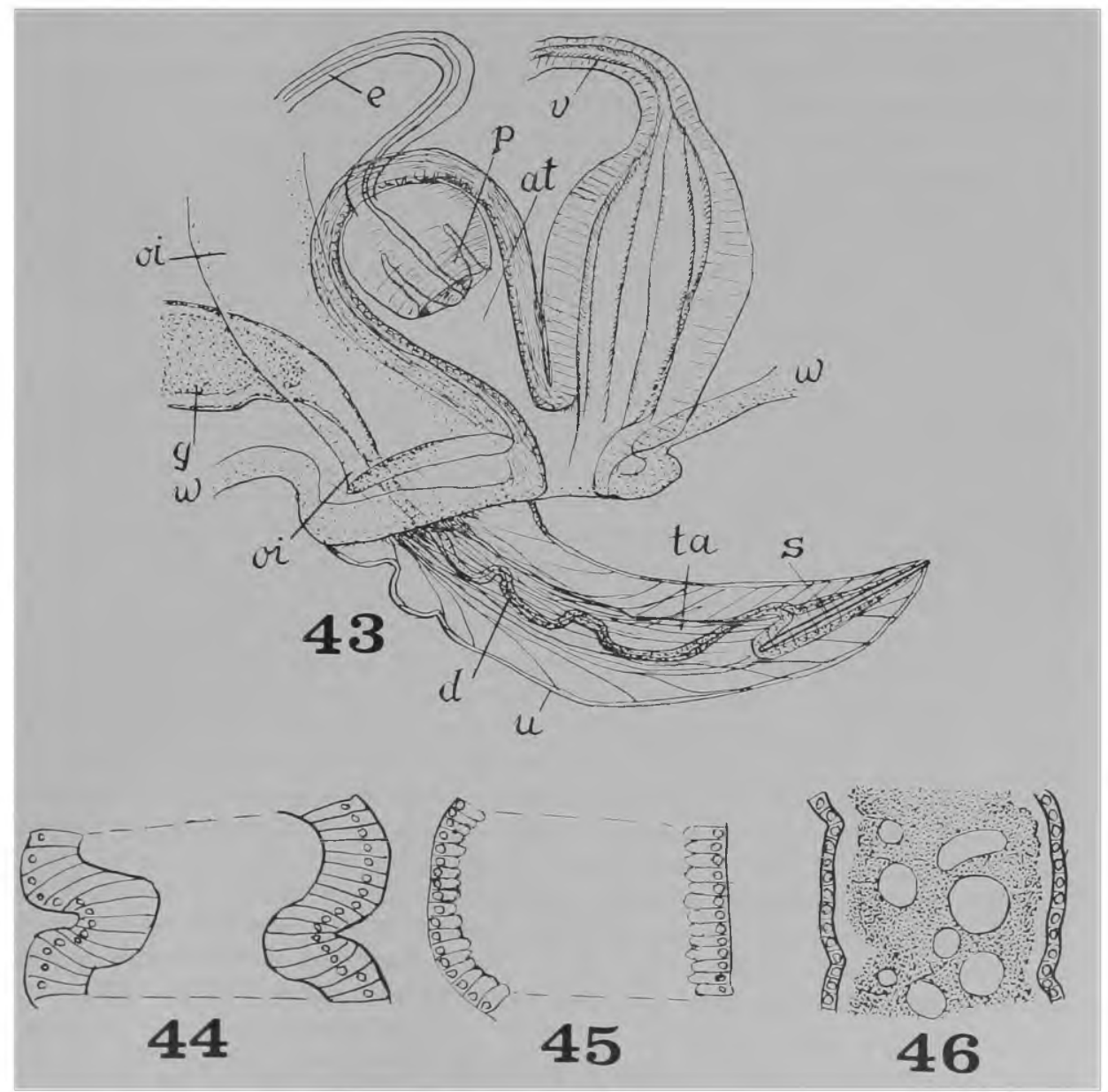

Figures 43-46 - Jorunna luisae

43 - Vagina, male atrium with completely retracted penial papilla, and vestibule completely everted. 44 - Optical section of part of prostate. 45 - same of ental, transparent part of vestibular gland. 46 - Same of ectal, opaque yellowish part of vestibular gland. 
a solid ball of disintegrating cells. The insemination duct (i) leaves the spermatheca to the side of the vaginal entrance, hence corresponding to Odhner's serial type $(1926 \mathrm{a}: 51,54)$, and is coiled on its way to the female gland mass $(\mathrm{m})$. Near its entrance into the latter the globular spermatocyst (c) is connected to it by a short duct.

From the atrium a further muscular pouch (u) goes inward, in the invaginated state lying between the body wall and the female gland mass. It leads to the vestibular gland (g), a long, wide tube zigzagging forward and backward, ending blind. The ental part of the gland is white with a $0.03 \mathrm{~mm}$ high epithelium and has a $0.2 \mathrm{~mm}$ wide lumen (Fig. 45). Beyond the bend it has a flatter epithelium $(0.01 \mathrm{~mm})$, and its lumen is filled with finely granular, yellowish secretion and homogeneous balls of varying diameter lying embedded in it (Fig. 46). These colours correspond to those of the prostate of Jorunna malcolmi. The connexion to the vestibule is a long, narrow, coiled duct (d) opening laterally into a muscular diverticulum of the vestibule which contains the slender stylet (s), $0.3-0.64 \mathrm{~mm}$ long. The tip of this thickly muscular papilla is set off by a constriction from the vestibule into which it projects (Fig. 42) when the vestibule is invaginated (Fig. 39). Evaginated, the papilla is the tip of a penis-like projection of about $07 \mathrm{~mm}$ length (Fig. 43). The shape of the stylet is straight in some specimens with everted or retracted organ. In others the stylet is curved, parallel (Fig. 42) or opposed to the bend of the everting papilla.

Discussion. - The rich material published as tomentosa in a list (Schmekel, 1968: 116) allowed for a thorough study which resulted in the separation of the present Mediterranean material from that of tomentosa from Trieste and from the Atlantic coasts of Europe. The differences refer to its smaller size and to the labial rodlets. Swennen (1961: 197) had noted the smaller number of teeth in Vayssière's description of his Mediterranean animal which mentions labial rodlets (Vayssière, 1901: 32).

From malcolmi the present species differs by 4-5 slender marginals and by its well developed penial papilla, by its vestibule several times as long as the stylet. Though the differences from spazzola are insignificant, a little more numerous rhinophoral leaflets and teeth, the areae of the labial rodlets smaller, and the rodlets shorter than in spazzola, and the female gland mass of luisae much smaller relatively than that of spazzola, I keep the Mediterranean species separate from the Brasilian one. During the elaboration of the present paper I have learned the hard way, how difficult it is to separate species published under one and the same name ("lumped"), hence I leave it to future research to synonymize luisae with spazzola. Several species are known from both the Mediterranean and the Brasilian coasts, e. g., Spurilla neapolitana (Delle Chiaje, 1823).

12. Jorunna lemchei, spec. nov. Figures $47-52$

Material. - W Ireland, Ballyvaghan Bay, $53^{\circ} \mathrm{N}, 09^{\circ} \mathrm{W}$, lowermost tidal zone, under stones, 2 specimens 11 VIII.1971, Henning Lemche leg. 
W Ireland, $53^{\circ} 19^{\prime} \mathrm{N}, 09^{\circ} 40^{\prime} \mathrm{W}, 15.25 \mathrm{~m}$, diver. Gurraig Sound, SE of Inish Travin. 3.VI.1975, Henning Lemche leg.

\section{Holotype: USNM 710703}

Diagnosis. - Rather small Jorunna with caryophyllidia, 11-12 bipinnate gills, labial cuticle smooth, marginal teeth without denticles. Penial papilla and male atrium with cuticular spines. Vestibule much longer than vestibular stylet.

Description. - The strongly contracted largest animal measures $18 \mathrm{~mm}$ long, $12.5 \mathrm{~mm}$ broad and $9 \mathrm{~mm}$ high. The smaller, well stretched one is $15.5 \times 7 \times 6 \mathrm{~mm}$. The colour is cream without any spots, though there are melanophores preserved in the peritoneum. The notal knobs are true caryophyllidia of $0.2-0.3 \mathrm{~mm}$ height (Fig. 52). The supporting spicules project over the sensory tip and penetrate entally into the body wall. The unpigmented rhinophores have about 16 leaflets. The tentacles are pointed, they are broad and flat triangles. The borders of the rhinophoral sheaths and the gill cavity are beset with short caryophyllidia. There are 11-12 bipinnate gills. The anterior border of the foot is bilabiate and deeply notched.

The labial cuticle is smooth. The radular formula is $18-19 \times 2-5$. 18-19.0.18-19.2-5. The first lateral is broader than the others (Fig. 48). The slender marginals bear no denticles (Fig. 48). The peritoneum is stippled with small brown chromatophores. The stomach is covered by the digestive gland.

The female gland mass is of normal size. The hermaphrodite duct is distended by sperm as ampulla (Fig. 47, a). It divides, and the inner oviduct enters the female gland mass $(\mathrm{m})$. The male duct becomes glandular. This prostactic part (q) is folded upon itself and is continued into a narrow, muscular section (e) which opens into the muscular male atrium (at) on the tip of a penial papilla (p). In the large specimen the papilla is contracted and beset with pointed cuticular spines (Fig. 49). These were seen in the total clarified preparation. The reproductive organs of the younger animal were sectioned (Fig. 50) and show spines on the papilla as well as on the wall of the male atrium. The spines are solid and mostly blunt in the sections (Fig. 51), while they appear as hollow, pointed cones in the $18 \mathrm{~mm}$-specimen. In the smaller slug the fundus of the atrium or penial sheath is ciliated, and the spiny knobs are situated ectally. In the big animal the cuticular spines are located in the fundus and on the root of the penis.

The walls of the common atrium are stiffened by perpendicular spicules, 0.1-0.2 $\mathrm{mm}$ in length. Near the opening of the male atrium the vagina (v) enters. It is wide in its ectal part, whose epithelium is folded longitudinally. The entally following section is narrow and goes into the globular spermatheca (t), $0.22 \mathrm{~mm}$ in diameter. Beside the entrance, the insemination duct (i) leaves the spermatheca, giving off a short branch to the spermatocyst (c). The sperm in the spermatocyst is oriented with the heads towards the wall. The insemination duct meets the female duct 


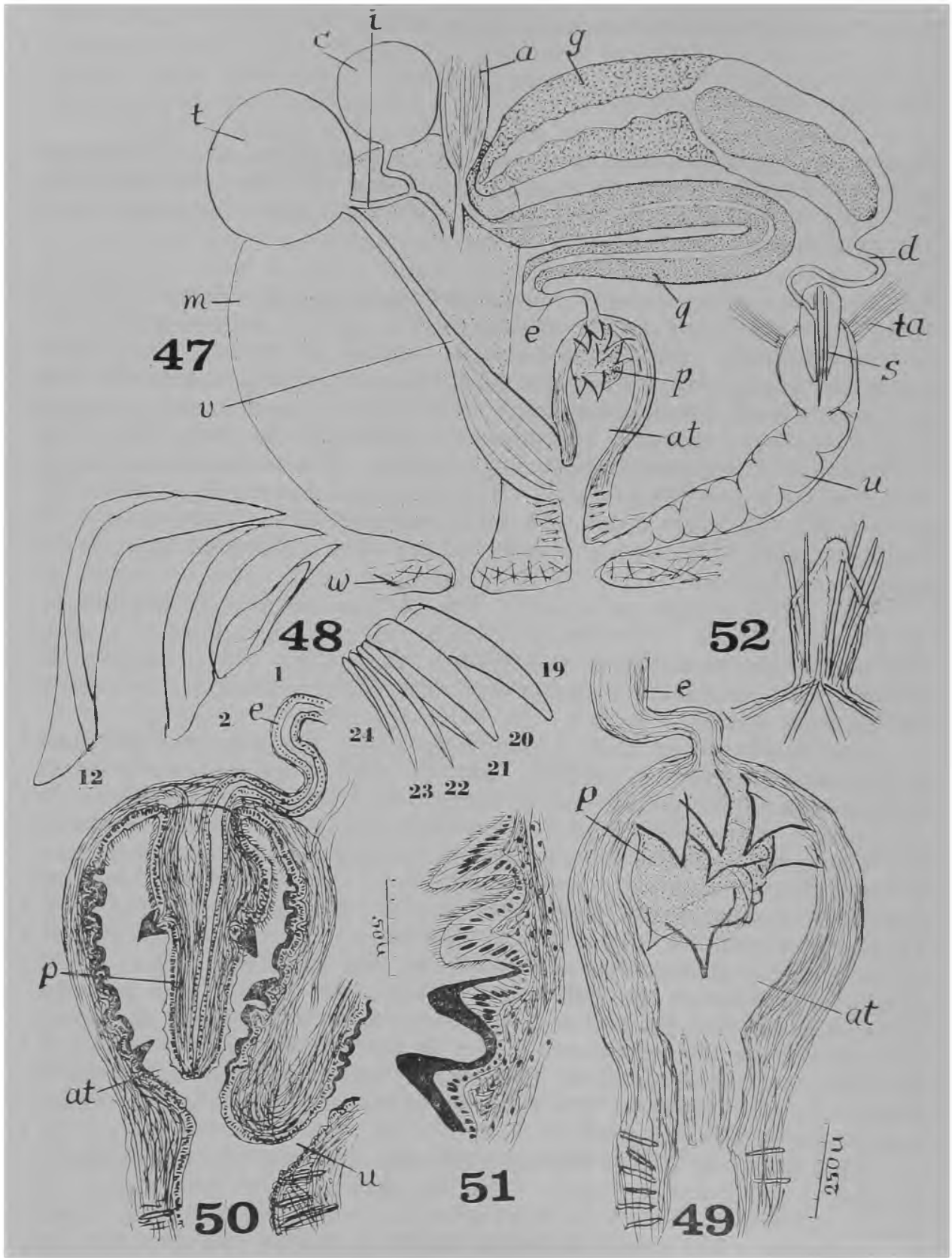

Figures 47-52 - Jorunna lemchei

47 - Diagram of reproductive organs. 48 - Radular teeth. 49 - Clarified penial bulb of specimen 1. 50 - Combined section of penial bulb of specimen 2 . 51 al Detail of same with higher power. 52 - Caryophyllidium of preserved specimen. 
in the female gland mass $(\mathrm{m})$. The outer oviduct coming from the gland mass opens beside the vestibule.

The long, tubular vestibular gland $(\mathrm{g})$ empties into a diverticulum of the vestibule (u) through a $0.4 \mathrm{~mm}$ long papilla bearing a $0.5 \mathrm{~mm}$ long stylet (s). The ental part of the gland is white with a high, glandular epithelium, the ectal part is thin-walled, and its wide lumen is filled with yellowish coagulated secretion. A connexion to the female duct, or to the sinus was not observed.

Discussion. - These specimens were received as Jorunna tomentosa, and they are externally not distinguishable from tomentosa, but that is true for most of the species of the genus. After I had called his attention, Dr. Lemche studied some good colour photographs of his living Jorunna from Anglesey and from West Ireland, and found the shape of the caryophyllidia different, cylindrical in the Welsh specimens, conical in the Irish ones. In the preserved specimens which I could examine, the difference is not noticeable, compare Figs. 12 and 52.

The marginal teeth of lemchei have no denticles, but also in tomentosa their occurrence is quite irregular (Figs. 14, 15). The Irish animals agree with those from Plymouth, Helgoland and Frederikshavn in the general aspect of their reproductive organs also. However, their distinctive feature is the spines in the male atrium and on the penial papilla. Though there are only two samples, the great number of larger animals of tomentosa never had spines. I consider this character as specific and dedicate the new species to its collector, my Friend Dr. Henning Lemche, to honour him on his seventieth birthday.

\section{Discussion of the genera Kentrodoris and Jorunna}

The genus Kentrodoris was introduced by Bergh (1876: 413), and in a footnote, on p. 414, he proposed Jorunna for Doris johnstoni Alder \& Hancock, 1845. So the type species for Jorunna is univocal. As the first species described in Kentrodoris is rubescens (1. c., p. 413), it can be accepted as type species.

During all the years while Bergh described Kentrodoris, he confused the male duct with its unarmed penial papilla and the duct of the vestibular gland with a stylet ("hasta amatoria") in the species he assigned to Kentrodoris. In his descriptions of Jorunna they were analyzed correctly, though he still criticized (1880: 48, note 3 ): "the representation of the penis (?) by Alder \& Hancock (1845, fam. 1, pl. 5, fig. 3) cannot be correct" In 1880 (p. 46) Bergh was "not entirely certain of a generic difference between the Jorunnae and Kentrodorides" He admitted (1881: 113-114) the unarmed penis and the vestibular stylet for Jorunna. For Kentrodoris a Hasta amatoria had not been verified, its stylet was attributed to the penis. Bergh complained (1881: 125, note 1): "Mangel hinlänglichen Materials ist mir überhaupt bei diesen so oft an und für sich schwierigen Untersuchungen von oft verwickelten Verhältnissen leider allzu häufig ein unüberwindlicher Stein des Anstosses gewesen" 


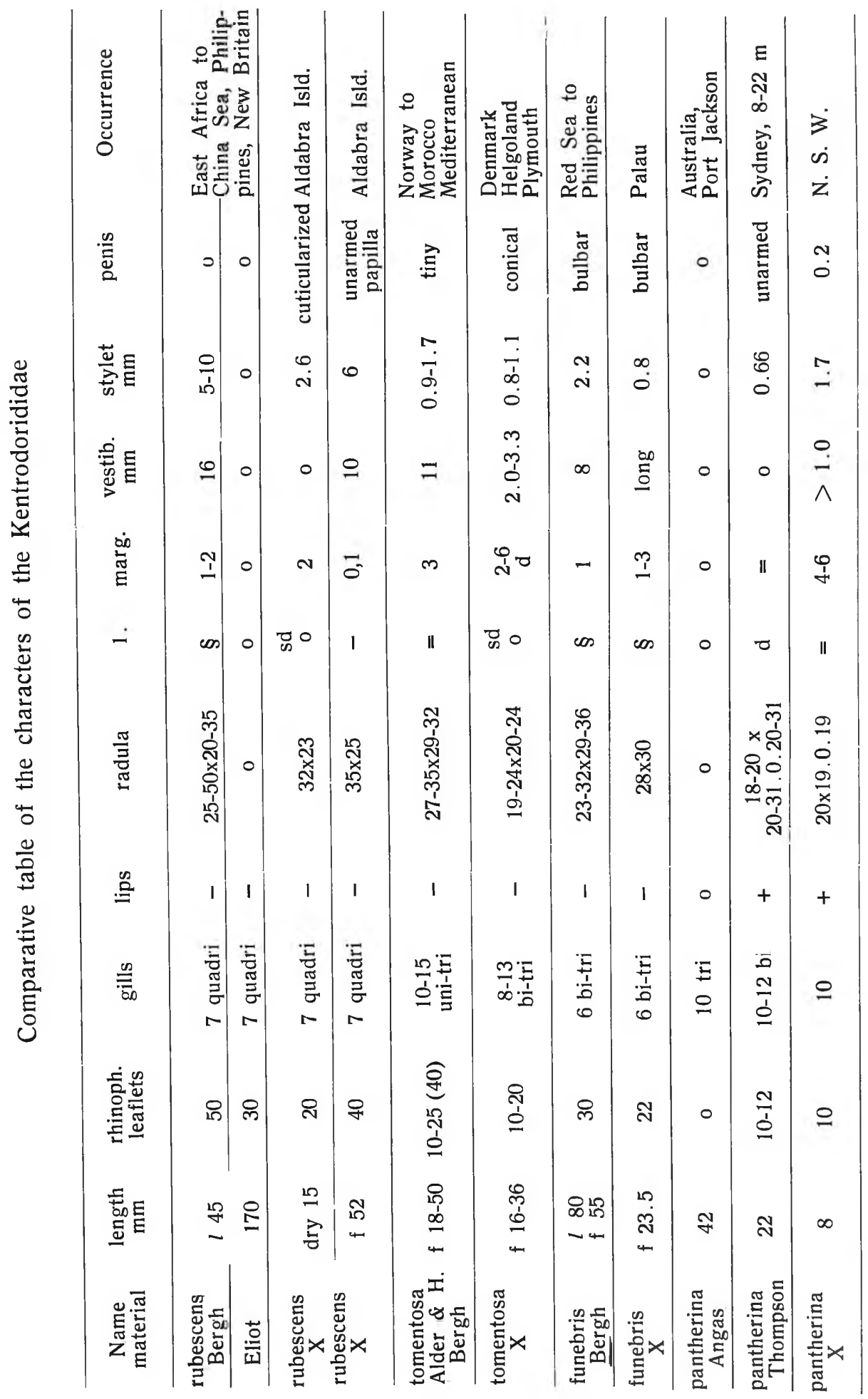




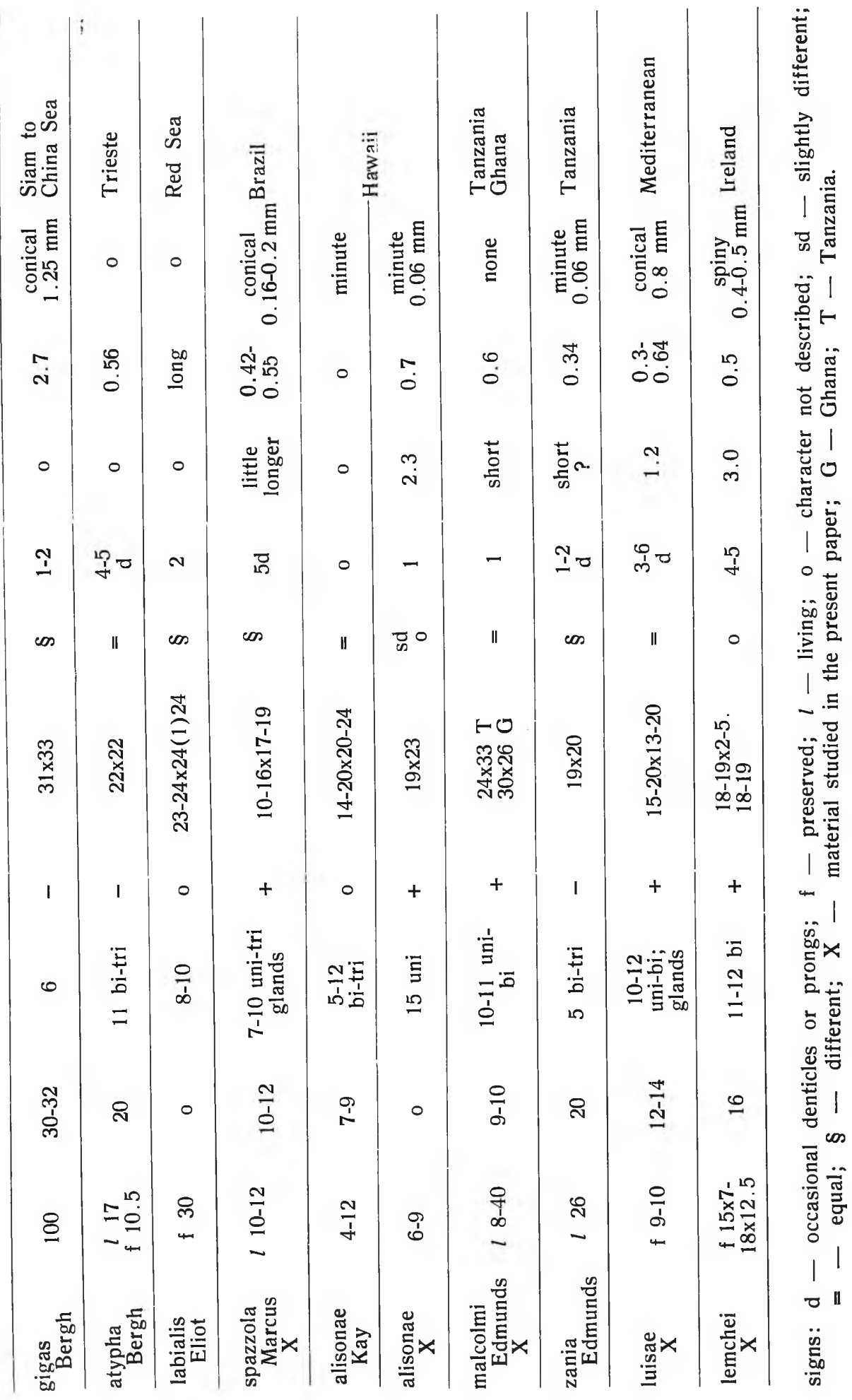


Following Bergh, Thiele (1931: 436) and Odhner (1968: 871) distinguished the two genera by an unarmed penis, Jorunna, and an armed one, Kentrodoris.

Odhner (1939: 36, fig. 18) had given a corrected figure for Jorunna tomentosa, but "Kentrodoris" was only studied by Edmunds in 1971 (p. 366, figs. 12,13$)$. He reconstructed the reproductive organs of " $K$. funebris" from sections and did not discuss the old misinterpretation, but thought that "Kentrodoris does not appear to be a well defined genus"

Caryophyllidia were described for Jorunna ? atypha by Bergh (1881: 127), for tomentosa by Garstang (1893), Vayssière (1901), and Labbé (1933), for malcolmi and zania by Edmunds (1971). They occur also in the present Kentrodoris rubescens, Jorunna funebris, pantherina, spazzola, alisonae, luisae and lemchei. Distinctly different types of notal papillae are figured for rubescens and gigas by Bergh (1876; Fig. 6). For the remaining species there are no sufficient indications. Caryophyllidia cannot be considered as generically distinctive, e. g., Peltodoris greeleyi MacFarland (1909: 84) has, and P. hummelincki Marcus (1963: 27) has no caryophyllidia.

From the contradictory statements: lips unarmed for both genera, while Vayssière and Edmunds found rodlets in Jorunna, and Eliot in Kentrodoris, and: salivary glands absent in Jorunna (Millott, 1937), and figured for Jorunna by Brygider (1914: 395, fig. 41) and Edmunds (1971, fig. 11 D), one can infer that the state of our knowledge is as unsatisfactory as it was for Bergh (1880: 46), and as Edmunds (1971: 368) still admitted, for separating the genera.

One character supposed to separate them is the shape of the gill, forming a cup in Jorunna, spread out in Kentrodoris. This feature is not recognizable with retracted gills or in preserved material. Moreover, Edmunds, in his letter of 27.II 1974, considers the gill arrangement in Jorunna and Kentrodoris as "purely adaptive - in tomentosa the erect, cup-shaped gills closely mimic the osculum of a sponge. By contrast, funebris (= zania) is not cryptic" Already Garstang (1893: 51) had noted "the remarkably sponge-like appearance of an individual of this species simulating the protruding osculum of a small Halichondria" In Jorunna spazzola the teeth conform to the old diagnosis of Jorunna, the gills to that of Kentrodoris.

As the type species of Kentrodoris, rubescens Bergh, is quite different in appearance from the rest of the species in Bergh's figure (1874, pl. 33, fig. 8) as well as in Eliot's (1903, pl. 34, fig. 7), and in the dry specimen I first received, due among other characters to the erect tuft of long gills, Edmunds suggested to allot all the others to a different genus (letter of 27. II.1974). The blunt teeth of the radula differ from the pointed ones of all the other species. The marginal teeth not different from the laterals occur also in several other species, as far as we have sufficiently detailed descriptions. Jorunna tomentosa, atypha, spazzola, alisonae, luisae and lemchei have generally more than one marginal tooth different from the rest.

As I was fortunate to obtain two specimens of rubescens for dissecting, I could complete Bergh's diagnosis, and found the male organ so far different from those of the other species, that it furnishes a criterion for the separation of the genera Kentrodoris and Jorunna. Of the species 
known for their reproductive organs, $K$. rubescens is the only one with a cuticularized efferent duct, and with an acinous prostatic gland. So Kentrodoris rubescens, the type species of the genus, is now the only one really belonging to Kentrodoris; all the others are Jorunna.

The "lumping", that is, giving the name of a well-known species to new finds from other regions without a detailed study of their characters, and then copied in later lists, makes it extremely difficult to separate the really different species. While Bergh distinguished the genera in 1892 and 1897, he in the Iatter paper (p. 98) synonymized Doris maculosa Cuvier, 1804, D. funebris Kelaart, 1859, and Kentrodoris annuligera Bergh, 1876. Cuvier's species was re-examined by Pruvot-Fol (1934b: 220 ) and allotted to Discodoris; $K$. annuligera was considered as a junior synonym of $K$. funebris. Due to the incomplete descriptions most of the mentions cannot be distributed onto either Jorunna funebris or zania, both with black rings on the whitish notum. The same difficulty applies to tomentosa which was thought to be cosmopolitan, and its name used for animals from the Indian and Pacific Oceans. I must, in 1975, repeat the words of J. E. Gray (1859: 510-511): "These examples should, I think, make us much more careful than we have been in deciding what are and what are not distinct species, from comparison of the outer aspect alone" Gray dealt with shells.

As I luckily could examine nine species, I could compare the old indications with my own observations and with those of Edmunds, and came to the conclusion, contrary to Labbé (1933), that the genera are really well distinguished.

The position of Kentrodoris in the Dorididae, subfamily Kentrodoridinae, was mentioned in the introduction. The allotment of the related genera in many different subfamilies, according to the taste of the author, is a token of the unready state of our knowledge of the specific and generic characters of many of the insufficiently described forms.

In the recent treatise (Odhner in Franc, 1968: 834, 871) the Kentrodorididae are treated as family 14 of the suborder Eudoridacea-Cryptobranchia (p. 865), and comprise Audura Bergh, 1878, and Kentrodoris and Jorunna. The reproductive organs of Audura, erected upon a single specimen $(1878$ : 567-571; 1877, pl. 57, figs. 13-22, 24-25), were described with several question marks. In Bergh's system (1892: 1096) Audura is allotted to the Discodoridinae. The diagnosis mentions: "a transitory (?) Hasta amatoria" The teeth of the radula are all denticulate, the outermost are pectinate, so Audura is not closely related to the Kentrodoridinae. Of the remaining genera connected to the Kentrodoridinae by their vestibular gland with stylet, and penial papilla without stylet, Asteronotus cespitosus (van Hasselt, 1825) (Marcus, 1970b: 203, figs. 68-70; Edmunds, 1971: 361 , figs. $4 \mathrm{D}, \mathrm{E}, 10$ ) is nearest to Kentrodoris rubescens, due to its lobed spermatocyst. However, the very flat shape and notal bulges, consistency and colouring, the star-formed opening of the gill cavity, and the wanting of notal papillae distinguish it. A lobed spermatocyst occurs also in Sebadoris nubilosa (Pease, 1871) (Edmunds, 1971: 345, fig. 4 A). Nuvuca lurca Marcus, (1967: 621, figs. 48-50), Peronodoris rehderi Marcus (1970a: 165, figs. 27-30), and Pupsikus pinguis Marcus (ibid.: 167, figs. 33-38) differ from Kentrodoris by pectinate 
marginal teeth. Peronodoris and Pupsikus have denticulate lateral teeth, while those of Nuvuca are smooth. Of the four mentioned genera only Pupsikus has labial rodlets. The position of Peronodoris is still unsettled; $P$. rehderi has two stylets. The species allotted to the genus are not homogeneous.

I agree with Edmunds (1971: 361) that our knowledge is still insufficient to divide the Dorididae onto subfamilies, or corresponding higher taxa.

\section{Biological and anatomical notes}

I did not have the occasion for many observations of the living animals. Swennen (1961: 235) did not find $J$. tomentosa every year during his studies from 1948 to 1960 , though their food was available. He found the animals feeding on Halichondria panicea and sitting on Haliclona oculata. Also Hecht (1895: 623), Jaeckel (1952: 257), Thompson (1960: 126-127; 1964: 289) and Miller (1961: 110) indicated Halichondria panicea as food, while Helma Wolter (1967: 281) obtained Jorunna only from Adocia cinerea.

The living Jorunna tomentosa which I saw in Helgoland and Plymouth generally carried their gills broadly open, only exceptionally in cup-shape. Hoffmann (1940: 44) described the plicate, unipinnate gills of the Doridacea as consisting of a flat, ribbon-shaped main axis, on which simple lateral folded leaflets alternate on both sides, just as in the Pleurobranchidae (Köhler, 1893: 74). When the lateral leaflets increase in size, they in their turn fold into lateral leaflets, thus constituting bipinnate gills. When these secondary leaflets again produce lateral pinnules, the gills become tripinnate, and so ad infinitum. The principle of ramification is the same in the Cephalaspidea, e. g., Scaphander (Perrier \& Fischer, 1911 , fig. N). The structure is well visible in Jorunna in certain views of the gills (Fig. 19, left side), while in other views the leaflets appear like branches (right side). The number of gills is variable in one and the same species and increases with size.

The branchial glands of $J$. luisae (Fig. 38) are similar to those described for spazzola (Marcus, 1955: 157, fig. 191). They are generally smaller, $0.05-0.10 \mathrm{~mm}$ in diameter, and more numerous than in spazzola with a diameter of $0.10-0.15 \mathrm{~mm}$. They were also seen in tomentosa in great numbers, $0.15-0.30 \mathrm{~mm}$ in diameter, but less conspicuous among the folded branchial pinnae. These branchial glands were first described by Hecht (1895: 603, figs. 70, 71) in Goniodoris. Hecht supposed a defensive function. Nevertheless the gills of the doridids are appreciated as food and frequently found bitten off (personal information from Edmunds). Hoffmann (1940: 48) mentions several species for which branchial glands were reported.

The spawn of J. tomentosa was already described by Alder \& Hancock (1845, fam. 1, pl. 5, fig. 7). The specimens collected for me in Helgoland in June 1974 had spawned in the aquarium. The cream-colored ribbons were deposited on algae in spirals or in irregular loops (Figs. 16, 
17). They measured about $30 \mathrm{~cm}$ in length and 4-7 $\mathrm{mm}$ in breadth. M. C. Miller observed the development in 1958 (Thompson, 1967: table 1).

The animals were anesthetized in $\mathrm{Mg} \mathrm{Cl}_{2}$. Urethan did not serve the purpose. They were preserved for microscopic anatomical studies in $80 \%$ Alcohol, and some in Formalin-Seawater.

The salivary glands often show vestiges of torsion, winding around the oesophagus to the left. Amaudrut (1898: 275, pl. 10, figs. 79, 83) mentioned this position and figured it for Bulla ampulla (Linné) and Aplysia punctata (Cuvier). It is also seen in some figures in Hoffmann (1938, figs. 727 A, 732 C, E, F), though not mentioned in the text. It was observed in Phyllaplysia engeli Marcus (1955: 61, fig. 37). Minichev (1967: 157, fig. 42) showed the twisting salivary glands of some Cephalaspidea.

In sections of spazzola, alisonae and luisae and in total preparations of tomentosa a pair of flat, wide glands was found inside the inner peritoneal membrane (Fig. $23 \mathrm{~A}, 26, \mathrm{pm}$ ) which separates the visceral organs from the visceral cavity, the hemocoel. The membrane consists of connective tissue and a few muscle fibres and contains scarce chromatophores. It is not covered by an epithlial layer (Hoffmann, 1935: 526). The glands lie on the ventral side of the digestive gland and extend forward to the front of the visceral mass; the one on the right side thickens and penetrates between the reproductive organs. They are pericardial glands (Lang, 1900: 337, 343), traversed by ramifications of the aorta (Fig. 18). Their aspect in sections (Figs. 23 A, 26) resembles the figure by Righi (1965: 379, fig. 53) of the pericardial gland of Tegula. Possibly they correspond to the "Blasenzellen" which Kowalewsky found in Microhedyle tyrtowi (1901: 11, fig. 43'). In Jorunna they are quite flat (Fig. 18), contrary to Pelseneer's observation in Acteon (1894: 8, fig. 12) from sections, where the unpaired gland is compact. The "glande hématique" or "glande vasculaire sanguine" of Perrier (1889: 162) in many prosobranchs is also unpaired and compact, and originates from the pericardium.

In J. alisonae Kay \& Young (1969: 185, fig. 11 A) figured a connexion between the fundus of the vestibular gland and the female gland mass, where spermoviduct and insemination duct unite. Edmunds (1971: 364) figured such a duct also for malcolmi. From the reconstruction of serial sections of J. zania Edmunds (1971: 368, fig. 13 B) saw the duct ending near the aperture of the vestibule. My sections of J. spazzola (Fig. $25 \mathrm{~A}$, ev) and alisonae (Fig. $27 \mathrm{G}$ ) show the duct lined with a flat epithelium opening into the sinus surrounding the four genital ducts near their apertures in the tip of the genital papilla. The epithelium thins out gradually. I do not know what the function of this duct may be. However, it makes Bergh's confusing of the vestibular gland with stylet and the prostatic duct with unarmed penial papilla more understandable.

\section{Zoogeographical remarks}

Contrary to the supposition of Young (1967: 168) and Kay \& Young (1969: 184) Jorunna tomentosa is not cosmopolitan. The materials des- 
cribed from Hawaii and from Tanzania (Edmunds, 1971: 364) are separated as alisonae and malcolmi in the present paper from the European tomentosa found from Norway to the Mediterranean and Morocco. There are two further Mediterranean species, (?) atypha Bergh, and luisae, spec. nov., one from Ireland, lemchei, spec. nov., and one from the South Atlantic, spazzola (Marcus). The other species are from the Indian Ocean, Indo-Pacific, or Pacific. New material of the well defined Kentrodoris rubescens Bergh from Aldabra Island shows sligtly different characters in the two specimens. Jorunna funebris (Kelaart) is known from the Red Sea to the Palau Islands, while the specimens trom Tanzania are separated as new species zania. Jorunna gigas (Bergh) has been reported from the Gulf of Siam to the China Sea. Kentrodoris (?) labialis Eliot is known from the Red Sea only.

\section{REFERENCES}

ABRAHAM, Phineas S., 1877. Revision of the anthobranchiate nudibranchiate Mollusca, with descriptions or notices of fourty-one hitherto undescribed species. Proc. Zool. Soc. London, 1877 (2): 196-269, pls. 27-30.

ALDER, Joshua and Albany HANCOCK, 1845. A monograph of the British nudibranchiate Mollusca, part. 1. (Ray Society, London).

ALDER, Joshua and Albany HANCOCK, 1851. A monograph of the British nudibranchiate Mollusca, part 5. (Ray Society, London).

ALDER, Joshua and Albany HANCOCK, 1855. A monograph of the British nudibranchiate Mollusca, part 7. (Ray Society, London).

ALDER, Joshua and Albany HANCOCK, 1864. Notice on a collection of nudibranchiate Mollusca made in India. Transact. Zool. Soc. London, 5 (3): 113-148, pls. 28-33.

ALLAN, Joyce, 1947. Nudibranchia from the Clarence River Heads, North Coast, New South Wales. Rec. Austral. Mus., 21 (8): 433-463, pls. 41-43, map.

AMAUDRUT, Alexandre, 1898. La partie antérieure du tube digestif et la torsion chéz les Mollusques Gastéropodes. Ann. Sci. Nat., sér. 8, Zool. 7: 1-291, pls. 1-10.

ANGAS, George French, 1864. Description d'espèces nouvelles appartenant à plusiéurs genres de Mollusques Nudibranches des environs de Port Jackson. Journ. Conchyl., sér. 3,4 (12): 43-70, pls. 4-6.

BEBBINGTON, Alan and Thomas E. THOMPSON, 1968. Note sur les Opisthobranches du Bassin d'Arcachon. Actes Soc. Linn. Bordeaux, 105, sér. A (5): 1-35, 19 figs.

BERGH, Rudolf S., 1874. Malacologische Untersuchungen, in: Reisen im Archipel der Philippinen (Ed. by C. Semper) 2 (6): 247-285, pls. 32-35.

BERGH, Rudolf S., 1875. Malacologische Untersuchungen, 2 (8): 315-343, pls. 40-45.

BERGH, Rudolf S., 1876. Malacologische Untersuchungen, 2 (10): 377-427, pls. 49-53.

BERGH, Rudolf S., 1877. Malacologische Untersuchungen, 2 (11): 429-494, pls. 54-57.

BERGH, Rudolf S., 1878. Malacologische Untersuchungen, 2 (13): 547-601, pls. 62-65. 
BERGH, Rudolf S., 1880. On the nudibranchiate gastropod Mollusca of the North Pacific Ocean, with special reference to those of Alaska. Part 2. Proc. Acad. Nat. Sci. Philadelphia (1879, pl. 8, fig. 19), 1880: 40-127, pls. 9-16.

BERGH, Rudolf S., 1880a. Malacologische Untersuchungen, 4, Suppl. 2, 1-78, pls. A-F. BERGH, Rudolf S., 1881. Malacologische Untersuchungen, 4, Suppl. 2: 79-128, pls. G-L. BERGH, Rudolf S., 1884. Malacologische Untersuchungen, 2 (15): 647-754, pls. 69-76.

BERGH, Rudolf S., 1890. Die Nudibranchien des Sunda-Meeres. Malacologische Untersuchungen, 2 (17): 873-973, pls. 85-89; Appendix p. 974-991.

BERGH, Rudolf S., 1892. Malacologische Untersuchungen, 2 (18): 995-1168.

BERGH, Rudolf S., 1897. Opisthobranchiaten. Abh. Senckenb. Naturf. Ges., 24: 97-130, pls. 12, 13.

BERGH, Rudolf S., 1905. Malacologische Untersuchungen, 9 (6): 57-116, pls. 5-8.

BRYGIDER, Wolodymyr, 1914. Über den mikroskopischen Bau der Speicheldrüsen bei den Nudibranchia. Zeitschr. wiss. Zool., 110: 359-418, pls. 12-14.

BURN, Robert, 1958. Further Victorian Opisthobranchia. Journ. Malac. Soc. Australia, 2: 20-36, pls. 6, 7 .

BURN, Robert, 1962. Notes on a collection of Nudibranchia (Gastropoda: Dorididae and Dendrodorididae) from South Australia with remarks on the species of Basedow and Hedley, 1905. Mem. Nat. Mus. Melbourne, 25: 149-171, pl. 1.

BURN, Robert, 1966. Opisthobranchia. Mem Nat. Mus. Melbourne, 27: 265-288, 377384, 1 map.

BURN, Robert, 1969. A Memorial report on the Tom Crawford collection of Victorian Opisthobranchiata. Journ. Malac. Soc. Australia, 12: 64-106.

COLLINGWOOD, Cuthbert, 1859. The estuary of the Mersey considered as a locality for nudibranchiate Mollusca. Ann. Mag. nat. Hist., ser. 3, 3: 461-470.

CUÉNOT, Lucien, 1927. Contributions à la faune du Bassin d'Arcachon, II. Bull. Stat. Biol. Arcachon, 24: 229-308.

CUVIER, Georges, 1804. Mémoire sur le genre Doris G. Cuvier, 1804. Ann. Mus. Hist. Nat., 4: 447-473, pls. 73,74 .

DAWYDOFF, Constantin, 1952. Contribution à l'étude des Invertébrés de la faune marine benthique de l'Indochine. Bull. Biol. France, Suppl. 37: 1-158.

EDMLiNDS, Malcolm, 1971. Opisthobranchiate Mollusca from Tanzania, (Suborder DoriGiv(ea). Journ. Linnean Soc. London, Zool., 50: 339-396, pl. 1.

ELIOT, Charles N. E., 1903. On some nudibranchs from East Africa and Zanzibar. Parts 2, 3. Proc. Zool. Soc. London, 1903 (I): 250-257, (II) 354-385, pls. 32-34.

ELIOT, Charles N. E., 1905. Nudibranchs from the Indo-Pacific: I. Notes on a collection dredged near Karachi and Maskat. Journ. Conchol., 11: 237-256, pl. 5.

ELIOT, Charles N. E., 1906. On the nudibranchs of Southern India and Ceylon. Proc. Zool. Soc. London, 1906: 636-691, 999-1008, pls. 42-47.

ELIOT, Charles N. E., 1907. Nudibranchs from the Indo-Pacific. III. Journ. Conchol., 12 (3): 81-92. 
ELIOT, Charles N. E., 1908. Notes on a collection of Nudibranchs from the Red Sea. Journ. Linnean Soc. London, Zool., 31 (1907-1915) (204, 1908): 86-122.

ELIOT, Charles N. E., 1910a. A monograph of the British nudibranchiate Mollusca. Part 8 (Supplementary), 198 pp., 8 pls. (Ray Society, London).

ELIOT, Charles N. E., 1910b. Nudibranchs collected by Mr. Stanley Gardiner from the Indian Ocean in H. M. S. Sealark. Transact. Linn. Soc. London, ser. 2, 13 (3): 411-438, pl. 25 .

ENGEL, Hendrik and van EEKEN,, C. J., 1962. Red Sea Opisthobranchia from the coast of Israel and Sinai. Sea Fish. Res. Stat. Haifa, Bull., 30: 15-34.

FARRAN, George Philip, 1905. Report on the opisthobranchiate Mollusca collected by Prof. Herdman, at Ceylon, in 1902. Ceylon Pearl Oyster Fish., Suppl. Rep. 21: 329364, pls. 1-6.

GARSTANG, Walter, 1893. Notes on the structure and habits of Jorunna johnstoni. Conchologist, 2: 49-52.

GRAY, John Edward, 1859. On the difficulty of defining the species of Mollusca. Ann. Mag. nat. Hist., ser. 3, 3: 510-511.

GRIEG, James A., 1913. Nudibranchiate mollusker indsamlede av den Norske fiskeridamper "Michael Sars" Kong. Norske Vidensk. Selsk. Skr., 1912 (13): 1-13.

GUAN-YU, Lin, and Si TCHANG, 1965. Opisthobranchia from the intertidal zone of Hainan Island, China. Oceanol. Limnol. Sinica, 7: 1-20, pls. 1-3.

HAEFELFINGER, Hans-Rudolf, 1960. Catalogue des Opisthobranches de la Rade de Villefranche-sur-Mer et ses environs. Rev. Suisse Zool., 67 (1957): 323-351.

HANCOCK, Albany and D. EMBLETON, 1852. On the anatomy of Doris. Phil. Transact. Roy. Soc. London, 1852 (2): 207-252, pls. 12-17 (not seen).

HECHT, Émile, 1895. Contribution à l'étude des Nudibranches. Mém. Soc. Zool. France, 8: 539-711, pls. 1-5.

HOFFMANN, Hans, 1926. Opisthobranchia. Tierw. Nord-Ostsee (Ed. by G. Grimpe \& E. Wagler), IX c 1: 1-52, 30 figs.

HOFFMANN, Hans, 1932-1940. Opisthobranchia. In: Bronn, Kl. Ord. Tierreichs, 3, 2. Abt. Buch 3, I: XI + 1247 pp., 1 pl., II: 1-90.

IREDALE, Tom S. and Charles H. O'DONOGHUE, 1923. List of British Nudibranchiate Mollusca. Proc. Malac. Soc. London, 15 (2): 195-233 (not seen).

JAECKEL, Siegfried jun., 1952. Zur Verbreitung und Lebensweise der Opisthobranchier in der Nordsee. Kieler Meeresf., 8: 249-259.

JOHNSTON, George, 1838. Zoologica IV The Scottish Mollusca Nudibranchia. Ann. Nat. Hist. Mag., 1: 44-56, 115-125, pls. 2, 3.

KAY, E. Alison and David K. YOUNG, 1969. The Doridacea (Opisthobranchia; Mollusca) of the Hawaiian Islands. Pacific Science, 23: 172-231.

KELAART, E. F. 1859. Descriptions of new and little-known species of Ceylonese Nudibranchiate Mollusks. Ann. Mag. nat. Hist., ser. 3, 10: 291-304, 488-496.

KENNY, Ron, 1960. Some Opisthobranch Molluses from Queensland. Univ. Queensland Pap., Dep. Zool., 1 (8): 223-228. 
KENNY, Ron, 1970. A second collection of Opisthobranch Molluscs from Queensland. Univ. Queensland Pap., 3 (7): 83-96.

KOHLER, August, 1893. Beiträge zur Anatomie der Gattung Siphonaria. Zool. Jahrb. Anat., 7 (1894) (1, 1893): 1-92, pls. 1-6.

KOWALEVSKY, Alexandre, 1901. Les Hédylidés, étude anatomique. Mém. Acad. Sci. St. Pétersbourg, sér. 8, Cl. Phys.-Math., 12 (6) : 1-32, pls. 1-5.

LABBÉ, Alphonse, 1933. Les organes palléaux (caryophyllidies) des Doridiens. Arch. Zool. Expér. Génér., 75: 211-220.

LANG, Arnold, 1900. Lehrbuch der Vergleichenden Anatomie der wirbellosen Tiere. (2nd. ed.), 3 (1): VIII + 509 pp., 409 figs. (Gustav Fischer, Jena).

LEMCHE, Henning, 1929. Gastropoda Opisthobranchiata. Zoology of the Faroes, 53: $1-35$.

LIM, C. F. and L. M. CHOU, 1970. The dendrodorid and doridid nudibranchs of Singapore. Malayan Naturalist Journ., 23: 92-117.

MacFARLAND, Frank Mace, 1909. The opisthobranchiate Mollusca of the BrannerAgassiz Expedition to Brazil. Leland Stanford Jun. Univ. Publ., Univ. ser., 2: 1-104, pls. 1-19.

MARCUS, Ernesto, 1955. Opisthobranchia from Brazil. Bolm. Fac. Fil. Univ. S. Paulo, (zool.), 20: 89-262, pls. 1-30.

MARCUS, Ernesto, 1958. Notes on Opisthobranchia. Bolm. Inst. Oceanogr. S. Paulo, 7 (1956): 31-79, pls. 1-8.

MARCUS, Eveline and Ernesto MARCUS, 1963. Opisthobranchs from the Lesser Antilles. Stud. Fauna Curaçao, 19 (79): 1-76.

MARCUS, Eveline and Ernesto MARCUS, 1964. Verzeichnis der euthyneuren Meeresschnecken Brasiliens. Beitr. Neotrop. Fauna, 3: 195-206.

MARCUS, Ernst, 1965. Some Opisthobranchia from Micronesia. Malacologia, 3: 263-286.

MARCUS, Eveline and Ernst MARCUS, 1967. Opisthobranchs from the south-western Caribbean Sea. Bull. Mar. Sci., 17 (3): 597-628.

MARCUS, Ernesto and Eveline MARCUS, 1970a. Opisthobranch Mollusks from the Southern Tropical Pacific. Pacific Science, 24: 155-179.

MARCUS, Eveline and Ernst MARCUS, 1970b. Some Gastropods from Madagascar and West Mexico. Malacologia, 10: 181-223.

MARCUS, Eveline. 1970c. On some Opisthobranchis from Cananéia. Bolm. Zool. Biol. Mar. n.s. 27: 207-228, pls, 1-4.

MARCUS, Eveline, 1975. On an albinistic Nudibranch Gastropod. Ciência e Cultura, 27 (8): 893 .

MILLER, Michael C., 1961. Distribution and food of the nudibranchiate Mollusca of the south of the Isle of Man. Journ. Anim. Ecol. 30: 95-116.

MILLOTT, N. 1937. On the morphology of the alimentary canal, process of feeding, and physiology of digestion of the nudibranch mollusc Jorunna tomentosa (Cuvier). Phil. Transact. Roy Soc. London, Ser. B - Biol. Sci., 228 (551): 173-218.

MINICHEV, Yu S., 1967. Studies on the morphology of the lower Opisthobranchia. Akad. Nauk Leningrad, Trudy Zool. Inst., 44: 109-182, 1 pl.

NOBRE, Augusto, 1938-40. Moluscos marinhos e das águas salobras. Fauna Malacológica do Portugal. XXXII + 808 pp., pls. I-XIX, 1-87. (Comp. Edit. Minho, Barcelos). 
ODHNER, Nils Hjalmar, 1907. Northern and Arctic invertebrates in the collection of the Swedish State Museum (Riksmuseum). III. Opisthobranchia and Pteropoda. K. Svenska Akad. Handl., 41 (4): 1-118, pls. 1-3.

ODHNER, Nils Hjalmar, 1926a. Die Opisthobranchien. Further Zoological Res. Swed. Antarct. Exped. 1901-1903, 2 (1): 1-100, pls. 1-3.

ODHNER, Nils Hjalmar, 1926b. Nudibranchs and Lamellariids from the Trondhjem Fjord. K. Norske Vidensk. Selsk. Skr., 1926 (2): 1-36, pl. 1.

ODHNER, Nils Hjalmar, 1934. The Nudibranchiata, Brit. Antarct. ("Terra Nova") Exped. 1910. Nat. Hist. Rep. Brit. Mus. London, Zool., y (5): 229-309, pls. 1-3.

ODHNER, Nils Hjalmar, 1939. Opisthobranchiate Mollusca from the Western and Northern Coasts of Norway. Kong. Norske Vidensk. Selsk. Skr., 1939 (1): 1-93.

ODHNER, Nils Hjalmar, 1968. Opisthobranches. In: Franc, André, Gastéropodes. (Ed. by $\mathrm{P}$. Grassé), Traité de Zoologie, 5 (3): 608-893.

O'DONOGHUE, Charles H., 1922. Notes on the Nudibranchiate Mollusca from the Vancouver Island region. I. Colour variations. Transact. Canad. Inst. Toronto, 14: 123-130, pl. 2.

O'DONOGHUE, Charles H., 1929. Report on the Opisthobranchiata. Res. Cambridge Exp. Suez Canal 1924. Transact. Zool. Soc. London, 22 (6): 713-841.

O'DONOGHUE, Charles H., 1933. Kelaart's work on the Nudibranchiata of Ceylon. Proc. Malac. Soc. London, 20 (4): 221-226, pl. 19.

PELSENEER, Paul, 1894. Recherches sur divers Opisthobranches, Mém. Cour. Sei. Nat. Acad. Roy. Belgique, 53: I-III, 1-157, pls. 1-25.

PERRIER, Rémy, 1889. Recherches sur l'anatomie et l'histologie du rein des Gastéropodes prosobranches. Ann. Sci. Nat. Zool., sér. 7, 8: 61-315, pIs. 5-13.

PERRIER, Rémy et Henri FISCHER, 1911. Recherches anatomiques et histologiques sur la cavité palléale et ses dépendances chez les Bulléens. Ann. Sci. Nat. Zool., sér. 9, 14: $1-190$, pls. $1-9$.

PRUVOT-FOL, Alice, 1934a. Les Opisthobranches de Quoy et Gainnard. Arch. Mus. Hist. Nat. sér. 6, 11: 13-92, pl. 1.

PRUVOT-FOL, Alice, 1934b. Les Doridiens de Cuvier. Journ. Conchyl., 78: 209-261, pl. 2.

PRUVOT-FOL, Alice, 1951. Étude des Nudibranches de la Méditernanée, 2e. partie. Arch. Zool. Expér. Genér., 88: 1-80, pls. 1-4.

PRUVOT-FOL, Alice, 1953. Étude de quelques opisthobranches de la côte Atlantique du Maroc et du Sénégal. Trav. Inst. Chérifien, 5: 1-105, pls. 1-3.

PRUVOT-FOL, Alice, 1954. Mollusques Opisthobranches. Faune de Franse, 58: 1-460, pl. 1.

RIGHI, Gilberto, 1965. Sobre Tegula viridula (Gmelin, 1791). Bolm. Fac. Fil. Univ. S. Paulo, (zool.), 25: 325-390, pls. 1-12.

RISBEC, Jean, 1928. Contributions à l'étude des nudibranches Néo-Calédoniens. Faune Colon. Franc., 2: 1-328, pls. A-D, 1-12.

RISBEC, Jean, 1930. Nouvelle contribution à l'étude des Nudibranches Néo-Calédoniens. Ann. Inst. Océanogr. Paris, n. sér., 7: 263-298. 
RISBEC, Jean, 1953. Mollusques Nudibranches de la Nouvelle Calédoníe. Faune de l'Union Française, 15: 1-189.

RISBEC, Jean, 1956. Nuđibranches du Viet-Nam. Arch. Mus. Hist. Nat. sẻr. 7, 4: 1-34, pls. 1-22.

SARS, G. O., 1878. Bidrag til Kundskaben om Norges Arktiske Fauna. I. Mollusca Regionis Arcticae Norvegiae, 1-466, pls. 1-34, I-XVIII.

SCHMEKEL, Luise, 1968. Ascoglossa, Notaspidea und Nudibranchia im Litoral des Golfes von Neapel. Rev. Suisse Zool., 75: 103-155.

SWENNEN, C., 1961. Data on distribution, reproduction and ecology of the Nudibranchiate Mollusks occurring in the Netherlands. Netherl. Journ. Sea Research, 1: 191-240.

THIELE, Johannes, 1931. Handbuch der systematischen Weichtierkunde. 1: VI + 778 pp. Jena, Gustav Fischer.

THOMPSON, Thomas Everett, 1958. The natural history, embryology, larval biology and post-larval development of Adalaria proxima (Alder \& Hancock) (Gastropoda Opisthobranchia) Phil. Transact. Roy. Soc. London, ser. B, 242 (686): 1-58, 49 figs.

THOMPSON, Thomas Everett, 1960. Defensive adaptations in Opisthobranchs. Journ. mar. biol. Ass. U. K., 39: 123-134.

THOMPSON, Thomas Everett, 1964. Grazing and the life cycles of British Nudibranchs. Brit. Ecolog. Soc. Symposium, n.9 4: 275-297. (Blackwell, Oxford).

THOMPSON, Thomas Everett, 1967. Direct development in a nudibranch, Cadlina laevis, with a discussion of developmental processes in Opisthobranchiata. Journ. mar. biol. Ass. $U$. K., 47: 1-22, 8 figs.

VAYSSIERE, Albert, 1901. Recherches zoologiques et anatomiques sur Ies Mollusques Opisthobranches du Golfe de Marseille, 3me partie. Ann. Mus. Hist. Nat. Marseille, 6: 1-130, pls. 1-7.

WOLTER, Helma, 1967. Beiträge zur Biologie, Histologie und Sinnesphysiologie (insbesondere der Chemorezeption) einiger Nudibranchia (Mollusca Opisthobranchia) der Nordsee. Zeitschr. Morph. Ökol. Tiere, 60: 275-337.

YOUNG, David K., 1967. New records of Nudibranchia (Gastropoda Opisthobranchia) from the Central and West-Central Pacific with a deseription of a new species. Veliger, 10: 159-173.

YOUNG, David. K., 1969. The functional morphology of the feeding apparatus of some Indo-Westpacific Dorid Nudibranchs. Malacologia, 9: 421-446. 



\section{Explanation of lettering}

In the diagrams some of the organs are laid aside to show the connexions of the organs and not their mutual position.

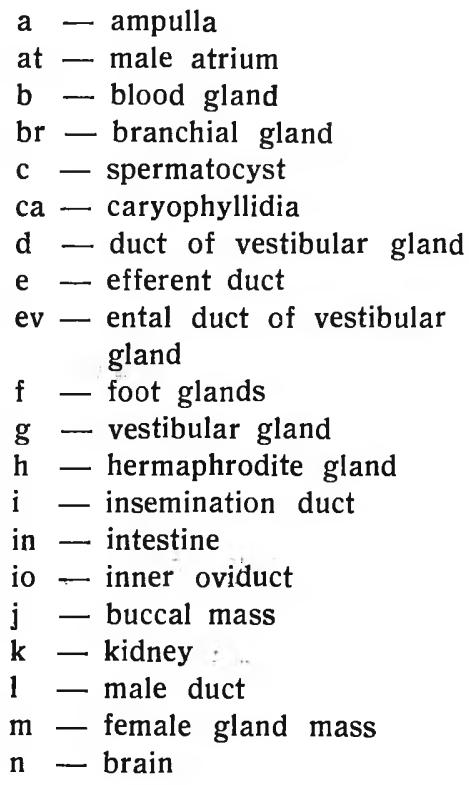

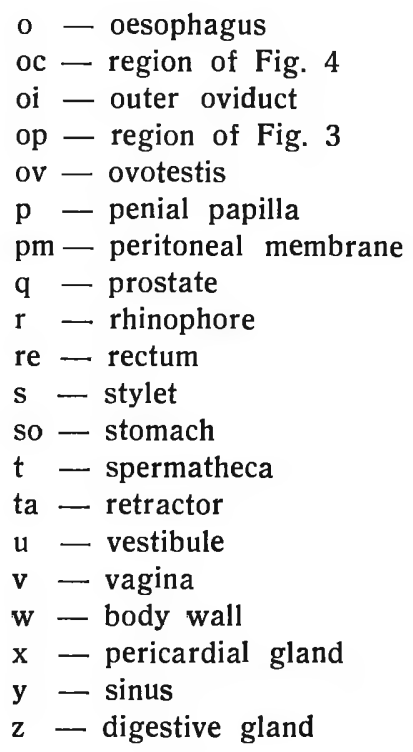


